\title{
Os estados de reformas defasadas e a questão da desvalorização: a reação da Venezuela aos choques exógenos de 1997-98
}

\author{
Outdated reform states and the issue of devaluation: \\ Venezuela's reaction to 1997-98 exogenous shocks
}

JAVIER CORRALES $*, * * * * *$

\begin{abstract}
RESUMO: Tendo acabado de completar sua segunda "década perdida” consecutiva, o caso venezuelano confirma que não há atalhos para uma boa gestão política econômica na era de alta mobilidade de capital e fluxos de capital securitizados. A manutenção de uma estratégia cambial atrapalhada triunfou, pelo menos por enquanto, e permitiu que uma coalizão de elite no nível executivo prevalecesse na busca de uma política macroeconômica menos do que ideal. O autor argumenta que a Venezuela evitou uma desvalorização total, do estilo mexicano ou brasileiro, em virtude da capacidade do Banco Central de gerenciar efetivamente a taxa de câmbio. No entanto, esse foi o único bolso da modernização, pois os formuladores de políticas de todo o resto da burocracia do estado rejeitaram os tipos de reformas de mercado que serão necessárias para reverter o desempenho altamente medíocre do país. Embora os altos preços do petróleo desde 1999 tenham proporcionado aos políticos e formuladores de políticas o "luxo" de ser um retardatário da reforma, os líderes venezuelanos parecem determinados a aprender da maneira mais difícil que as tendências internacionais podem voltar a balançar contra eles a qualquer momento.
\end{abstract}

PALAVRAS-CHAVE: Inflação; taxa de câmbio; crise cambial; economia política; reformas.

ABSTRACT: Having just completed its second consecutive "lost decade", the Venezuelan case confirms that there are no short cuts to sound political economic management in the era of high capital mobility and securitized capital flows. The maintenance of a muddling-through exchange rate strategy has triumphed, at least for the time being, and enabled an elite executive-level coalition to prevail in pursuing a less than optimal macroeconomic policy. The author argues that Venezuela has avoided a full-blown Mexican or Brazilian-style devalua-

\footnotetext{
* Professor-Assistente de Ciência Política do Amherst College, Amherst/MA, U.S.A. E-mail: jcorrales@ amherst.edu. Orcid https://orcid.org/0000-0001-7180-2826.

**Agradeço a Roberto Bottome, Delia Boylan, Imelda Cisneros, Jorge I. Domínguez, Jeanne K. Giraldo, Janet Kelly, Moritz Kraemer, Manuel Lago, James Mahon, Pedro Palma, Abdón Suzzarini, Germán Utretras, Beth Yarbrough e aos que contribuíram com seus comentários..

** Tradução de Renata Maria Parreira Cordeiro.
} 
tion by virtue of the Central Bank's ability to effectively manage the exchange rate. However, this has been the only pocket of modernization, as policymakers throughout the rest of the state bureaucracy have rejected the kinds of market reforms that will be necessary to reverse the country's highly mediocre performance. While high oil prices since 1999 have afforded politicians and policymakers the "luxury" of being a reform laggard, Venezuelan leaders seem determined to learn the hard way that international trends could again swing against them on a moment's notice.

KEYWORDS: Inflation; Exchange rate; currency crisis; political economy; reforms. JEL Classification: F31; F32; E31.

Não é incomum aos países em desenvolvimento reagir a choques econômicos externos pela recusa à desvalorização de suas moedas. Essa reação, muitos economistas sustentam, está repleta de altos custos e riscos. Custa muito porque leva à supervalorização da moeda, ao golpe na diversificação das exportações e à acentuada deterioração do nível de empregos. É arriscada porque defender uma moeda já supervalorizada em meio a desequilíbrios macroeconômicos geralmente não dá certo, levando a uma desvalorização muito mais ampla do que o esperado ${ }^{1}$ Ademais, é desafiadora, porque vai contra a recomendação dos politicamente poderosos especialistas em economia, inclusive das autoridades do Fundo Monetário Internacional (FMI), que, invariavelmente, recomendam uma desvalorização mesclada com reformas estruturais. E há ainda aqueles países que reagem a choques externos pela defesa, em vez da desvalorização, de suas moedas. ${ }^{2}$ Por que muitos países em desenvolvimento são atraídos por uma política econômica de defesa da moeda, apesar desses custos, riscos e recomendação? Para identificar as razões dessa escolha, este capítulo revê o caso da Venezuela, que reagiu aos choques exógenos de 1998 pela recusa à desvalorização.

Desde meados dos anos 80 , a Venezuela tem passado por vários ciclos de reformas "start-and-stop", "interrompidas e reiniciadas". Cada nova administração lança um programa de reformas econômicas, só para afrouxá-lo prematuramente, culminando numa crise econômica profunda. Além do mais, a Venezuela é a quintessência dos Estados de reformas defasadas. Por volta do fim dos anos 90, a Venezuela ainda tinha de consolidar um pacote completo de reformas de mercado de primeira geração, e quando o implantou ficou à parte da maioria dos países latino-americanos, que deram grandes passos na reforma de suas economias durante os

\footnotetext{
${ }^{1}$ Ver o capítulo de W. Max Corden neste volume.

${ }^{2}$ A grande tendência nos anos 90 foi passar dos regimes de taxas de câmbio fixas para regimes mais flexíveis, voltados para o mercado. Estes são distinguidos pelo Fundo Monetário Internacional (FMI) entre regimes muito flexíveis (taxas de câmbio flutuantes e independentes) e menos flexíveis (flutuação controlada). A Venezuela, junto com os outros 53 países dos cem examinados, pertencia à segunda categoria em dezembro de 1997. Fundo Monetário Internacional, Exchange Rate Arrangements and Currency Convertibility: Developments and Issues (Washington, 1999), pp. 25-6.
} 
anos $90 .{ }^{3}$ Foi nesse contexto de reformas defasadas que a Venezuela passou por um dos seus mais graves choques econômicos dos últimos quinze anos. Muitos especialistas e grupos de pressão, inclusive a poderosa companhia estatal de petróleo Petróleos de Venezuela S.A. (PDVSA), clamavam por uma maior desvalorização junto com um pacote de ajustes fiscais e de reformas microeconômica s. O governo venezuelano escolheu, em vez de defender o supervalorizado bolívar, aumentar as taxas de juros e queimar as reservas. Em suma, a reação do Estado venezuelano foi retrair, em vez de afrouxar, a sua já restritiva política econômica monetária e o seu regime inflexível de taxas de câmbio. ${ }^{4}$ As autoridades governamentais compreenderam os custos e riscos contidos nessa escolha. Bastou-lhes olhar para a história do seu próprio país para perceber que resistir às pressões pela desvalorização se mostra amiúde contraproducente. Então por que as autoridades venezuelanas seguiram o mesmo caminho de novo? Em linhas gerais, por que os países economicamente castigados reagem aos choques externos tentando manter um regime de taxas de câmbio fixo ou rigidamente controlado?

Este capítulo sustenta que a resposta vem das políticas locais em geral, e das variáveis inerentes ao Estado em particular. Quando os países de reformas defasadas passam por choques exógenos, defender um rígido regime de taxas de câmbio surge como uma reação politicamente promissora, ou melhor, como a reação política mais viável disponível ao Estado. A inabilidade para a consolidação das reformas econômicas deixa ao Estado muito poucos instrumentos de política econômica com os quais reagir aos choques quando estes ocorrem. A maioria das instituições estatais fica desorientada e incapaz de dar respostas confiáveis. Como Stephan Haggard sustentou na sua discussão da escolha dos modelos desenvolvimentistas

\footnotetext{
${ }^{3}$ Para uma visão geral da transição latino-americana para o mercado, ver William P. Glade, "The Latin American Economies Restructures, Again”, in Jan Knippers Black, org., Latin America: Its Problems and Its Promise (Boulder: Westview Press, 1998), pp. 145-61; Inter-American Development Bank, Latin America after a Decade of Reforms (Washington, 1996); Sebastian Edwards, Crisis and Reform in Latin America: From Despair to Hope (Oxford University Press, 1995); Augusto Varas, "Latin America: Toward a New Reliance on the Market", in Barbara Stallings, org., Global Change, Regional Response (Cambridge University Press, 1995), pp. 272-308; Samuel Morley, Roberto Machado, e Stefano Pettinaro, Indexes of Structural Reform in Latin America, Serie Reformas Económicas, vol. 12 (Santiago: Economic Commision for Latin America and the Caribbean, 1999); Philip Oxhorn e Graciela Ducatenzeiler, "The Problematic Relationship between Economic and Political Liberalization: Some Theoretical Considerations", in Philip Oxhorn e Pamela K. Starr, orgs., Markets and Democracy in Latin America: Conflict or Convergence? (Boulder: Lynne Rienner, 1999); e William Ratliff, " Development and Civil Society in Latin America and Asia ", Annals of American Academy of Political and Social Science, vol. 565 (setembro de 1999), pp. 91-112.

${ }^{4}$ Um estudo sobre os onze países latino-americanos revela que a Venezuela teve uma das mais inflexíveis taxas de câmbio em resposta à crise russa: a taxa de câmbio venezuelana mudou cerca de 1,51\% entre julho e outubro de 1998. Só quatro países foram mais inflexíveis: Argentina $(0,00)$, Chile $(0,58)$, Panamá $(0,00)$ e Uruguai $(1,40)$. Outros países passaram por maiores mudanças: Brasil $(2,65)$, Colômbia $(12,87)$, Costa Rica $(2,78)$, Equador $(25,72)$, México $(13,90)$ e Peru $(4,78)$. Ver Michaele Gavin, "Latin America Central Banks: Reticent to React", Latin American Economic Policies, vol. 7 (Washington: InterAmerican Development Bank, 1999), p. 3.
} 
do pós-guerra asiático e latino-americano, os Estados reagem aos imperativos econômicos não necessariamente através da implementação do que é ótimo do ponto de vista econômico, mas do que é praticável dentro "da esfera dos instrumentos de política econômica que o Estado comanda". ${ }^{5}$ Os membros do governo venezuelano aperceberam-se de que a recomendação do FMI de desvalorização, somada a reformas estruturais, era impraticável, não porque era economicamente infundada ou melhor, o inverso -mas porque o Estado não podia executá-la. O Estado se confrontou com uma crise de credibilidade. Estava de mãos amarradas pelos grupos de pressão e partidos políticos. A única instituição estatal imune a essa crise de credibilidade e paralisia, pensaram os membros do governo, era o Banco Central. Portanto, deu-se ao Banco Central total controle para tratar da crise. E o Banco Central fez aquilo que os bancos centrais fazem melhor: criou políticas de taxas de câmbio monetariamente restritivas e estabilizadoras. Assim sendo, o Estado venezuelano reagiu explorando a sua própria vantagem institucional, ou seja, confiando no Banco Central, apesar das pressões em contrário por parte da sociedade.

Este capítulo também mostra que os governos dão ensejo a algo mais além de uma simples e estrita análise custo-benefício quando implantam políticas de taxas de câmbio. As autoridades venezuelanas tinham duas outras considerações em mente. Uma delas era a necessidade de dar mostras de credibilidade. Escolheram a taxa de câmbio com esse objetivo uma vez que se trata de um dos indicadores mais visíveis e altamente observados em qualquer economia em desenvolvimento - uma estratégia sinalizadora ideal. A outra consideração era uma estimativa da probabilidade de insucesso. O governo sabia que qualquer política econômica, desvalorizar ou defender, poderia resultar num cenário de pesadelo, a saber: no fracasso em convencer os especuladores, que poderia finalmente levar à maxidesvalorização. Porém, o governo julgava que defender o bolívar tinha menor probabilidade de produzir esse resultado do que se envolver com uma desvalorização administrada. Isso porque os criadores de políticas econômicas perceberam que o Banco Central era a única agência do Estado capaz de aderir a uma orientação político-econômica escolhida, apesar das pressões da sociedade. Apostando no Banco Central, o governo não teve dúvidas em correr um risco, mas um risco indicado por uma avaliação racional de forças institucionais.

A surpresa da história venezuelana é que o Estado atingiu seus objetivos. O Banco Central derrotou uma das mais sérias crises monetárias da América Latina, evitando uma maxivalorização. Poucos países com fundamentos econômicos tão pobres como os da Venezuela em 1998 conseguiram fazer isso. A Colômbia, o Equador e o Brasil tentaram, mas não foram bem-sucedidos. Este capítulo também procura explicar o relativo sucesso da Venezuela no controle de uma crise monetária potencial, sustentando que esse resultado teve menos a ver com o nível de reservas do que com o nível de resoluções.

\footnotetext{
${ }^{5}$ Stephan Haggard, Pathways from the Periphery: The Politics of Growth in Newly Industrializing Countries (Cornell University Press, 1990), p. 45
} 
Enfim, este capítulo reitera os perigos de ser um país de reformas defasadas na era da globalização. Alguns economistas políticos têm sustentado que a implementação das reformas orientadas pelo mercado, que expõe as nações tanto à competição mais acirrada, quanto aos fluxos voláteis do capital, restringe a capacidade dos Estados de administrar os negócios econômicos. Em contraste, este capítulo sustenta que um Estado de reformas defasadas se torna muito mais restritivo. A inabilidade venezuelana para consolidar um programa de reformas necessárias deixou o país mais vulnerável aos choques externos, mais forçado a reações político-econômicas, e mais propenso a seguir políticas econômicas mais custosas no fim do processo.

\section{OS TRÊS CHOQUES DE 1997-1998}

Que tipos de choques podem agitar um mercado emergente? A resposta que os analistas tipicamente sugerem é crise financeira internacional, queda vertiginosa no preço das principais exportações de um país ou aumento da incerteza política local. Se for suficientemente grave, qualquer um desses choques pode causar a destruição dos mercados monetários, possivelmente mergulhando o país numa profunda crise econômica. A Venezuela em 1998 passou por todos os três choques de forma intensa e simultânea. $\mathrm{O}$ resultado foi, como era de se prever, uma série de pânicos financeiros que levaram a uma das recessões econômicas mais sérias que já se viu, um dos piores desempenhos econômicos naquele ano e ao colapso de um sistema político de trinta anos.

O primeiro choque externo teve origem na crise financeira asiática que começou a se desenrolar na segunda metade de 1997. Essa crise produziu uma desaceleração do PIB real do mundo, de 4,2\% em 1997 para 2,5\% em 1998, um declínio no crescimento do comércio mundial de $9,9 \%$ para $3,6 \%$ e um pânico completo nos mercados financeiros internacionais ${ }^{6}$ Como houve uma compressão nos mercados capitais, os investidores logo correram para os mercados emergentes economicamente frágeis que levassem a ataques especulativos em muitas moedas. Quando a Rússia foi forçada a desvalorizar - e depois não honrou - suas dívidas importantes, o pânico internacional se alastrou. A Venezuela, que havia atraído investimentos estrangeiros significativos após 1996 devido ao lançamento de um programa de reformas de mercado nesse mesmo ano, denominado "Agenda Venezuela", se tornou o próximo alvo de fuga de capitais.

O segundo e mais importante choque econômico foi o declínio vertiginoso do preço do petróleo. A Venezuela é um dos mais importantes exportadores de petró-

\footnotetext{
${ }^{6}$ Fundo Monetário Internacional, World Economic Outlook: October 1999 (Washington, 1999). A menos que seja indicado de outra forma, as estatísticas econômicas sobre a Venezuela são obtidas de várias fontes do Banco Central da Venezuela. Todos os valores são expressos em dólares norteamericanos.
} 
leo do mundo, membro fundador da Organização dos Países Exportadores de Petróleo (OPEP) e o principal fornecedor de petróleo para os Estados Unidos. Em 1997, o petróleo representava $80 \%$ da exportação da receita bruta da Venezuela e mais de $60 \%$ da sua renda fiscal. ${ }^{7}$ Uma das consequências da crise asiática foi reduzir a demanda mundial de petróleo. Além disso, a OPEP decidiu aumentar a produção de petróleo no fim de 1997. Embora a OPEP (e o México, a Noruega e o Egito) tenha efetuado reduções em 1998, estas foram contrabalançadas pela decisão dos Estados Unidos de permitir que o Iraque aumentasse o seu patamar de produção. O resultado foi uma baixa demanda e um alto fornecimento de petróleo, que diminuiu seu preço ao longo de 1998. Enquanto o Orçamento venezuelano de 1998 foi originalmente calculado sobre o aumento da média do preço do petróleo de $\$ 15,50$ por barril, o preço real por volta do fim de 1998 chegou quase a $\$ 9,65$ por barril, o menor em mais de duas décadas. Os preços do petróleo aumentaram vertiginosamente em 1999, portanto fica difícil lembrar a queda em $37 \%$ nos seus respectivos preços em 1997-98. Embora de curta duração, essa queda foi séria: praticamente dizimou os recursos fiscais da Venezuela em 1998-99.

O terceiro choque foi o aumento do risco político causado pelos inusitados altos níveis de incerteza eleitoral. Iniciando-se em abril de 1998, as pesquisas de opinião pública revelaram que o vencedor na eleição presidencial naquele mês de dezembro seria, provavelmente, Hugo Chávez Frias, o candidato com as mais antagônicas opiniões acerca das reformas de mercado. Desconhecido dos venezuelanos antes de 1992, Chávez tornou-se politicamente proeminente quando armou um golpe fracassado em fevereiro de 1992 contra a administração de Carlos Andrés Pérez (1989-93), um dos governos mais voltados para o mercado que a Venezuela já teve. Durante 1998, Chávez conduziu uma campanha altamente populista e nacionalista, temperada com repetidos ataques contra o "capitalismo selvagem". Ele criticou as privatizações essenciais, como as realizadas nos setores de alumínio e ferro, e entabulou um vingativo discurso contra o sistema. ${ }^{8}$ Falava de uma "revolução" que, embora "pacífica”, poderia punir os culpados pela corrupção. Os agentes econômicos entraram em pânico. ${ }^{9}$ Três cenários pareciam possíveis, todos igualmente preocupantes - um golpe para impedir a vitória de Chávez, uma reação maciça por ele liderada, caso perdesse as eleições, ou uma economia arruinada, bem como uma desordem política, caso ele ganhasse as eleições.

A primeira vítima desses choques foi a Bolsa de Valores de Caracas, que caiu mais da metade entre setembro de 1997 e junho de $1998 .{ }^{10} \mathrm{~A}$ queda precipitou um

\footnotetext{
${ }^{7}$ Congreso de la República, Informe de coyuntura, primer trimestre de 1999, Series Informes, 99-005 (Caracas, abril de 1999 ).

${ }^{8}$ Ver Economy Monthly, vol. 16 (abril de 1999), p. 8.

${ }^{9}$ Ver Jennifer McCoy, “ Chávez and the End of 'Partyarchy' in Venezuela”, Journal of Democracy, vol. 10 (Julho de 1999), pp. 64-77.

${ }^{10} \mathrm{O}$ índice da Bolsa de Valores caiu de 10.489 pontos em setembro de 1997 para 4.802 pontos em junho de 1998.
} 


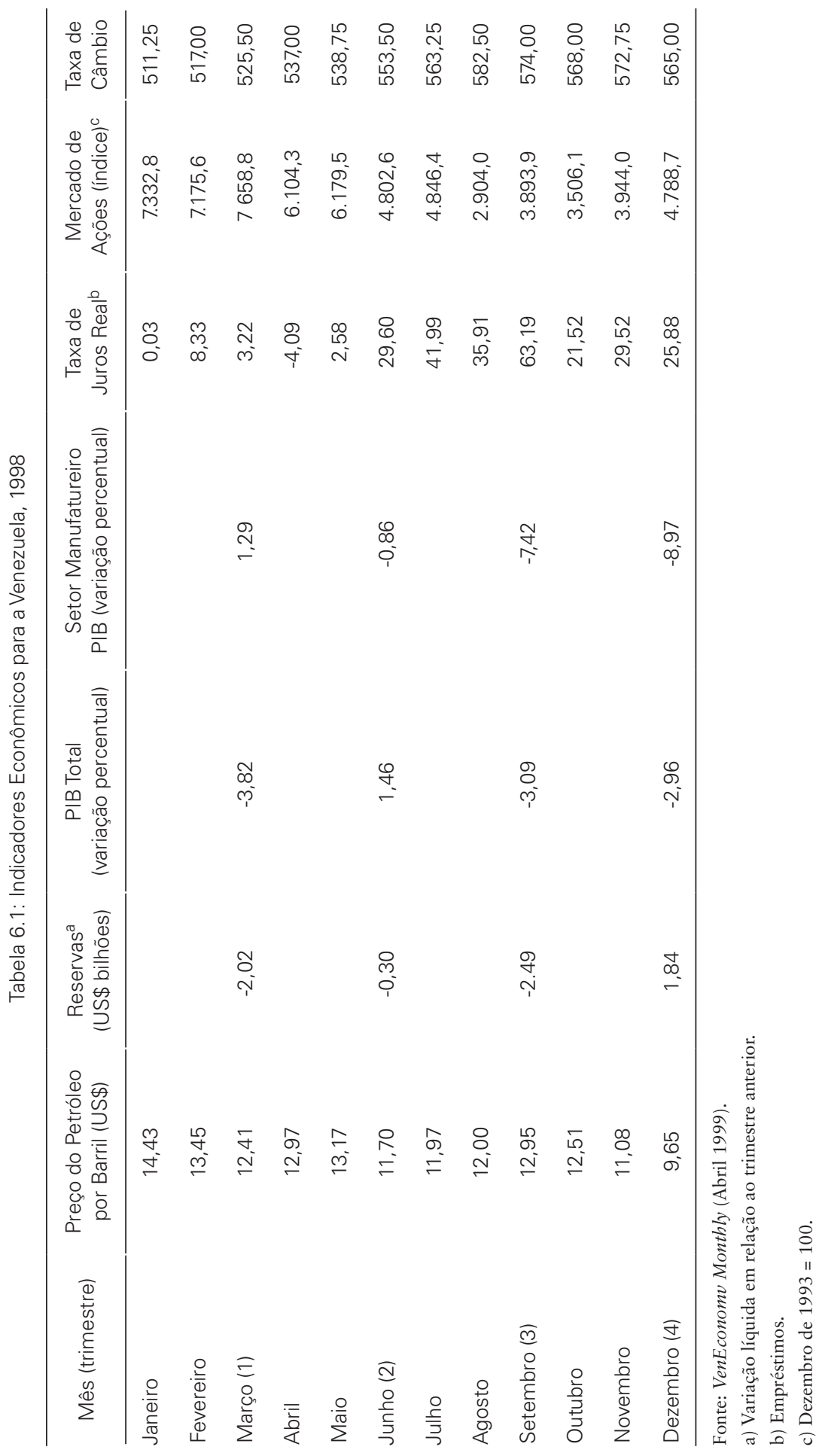


ataque especulativo contra o bolívar em maio de 1998. O governo reestruturou o Orçamento a fim de refletir o novo preço do petróleo mais baixo, para uma total diminuição nominal nos gastos de 5,9\%. A combinação de fuga de capitais e menores gastos operou uma grave recessão econômica no segundo semestre de 1998, que foi especialmente onerosa para o setor de manufaturados (ver tabela 6.1).

Essa recessão, no entanto, era só o começo. Por volta de agosto de 1998, um pouco depois do desastre russo, os investidores iniciaram uma segunda corrida desordenada ao bolívar. Para muitos investidores externos, a Venezuela era por demais semelhante à Rússia: as exportações de petróleo eram dominantes, as reformas econômicas estavam paralisadas e as forças políticas anti-mercado ganhavam poder. Cresciam as expectativas de eminente desvalorização do bolívar. Nessa altura, a Bolsa de Valores venezuelana essencialmente evaporou, caindo para os exatos 2.904 pontos por volta do fim de agosto - um declínio de $75 \%$ num ano.

O governo venezuelano reagiu ajustando integralmente a diminuição na demanda por dólares. Por volta do terceiro trimestre de 1998, o Banco Central esgotou $\$ 4,8$ bilhões em reservas (uma queda de $27 \%$ a partir de dezembro de 1997 ). Além disso, o Banco Central criou uma política econômica altamente restritiva, aumentando o rendimento dos títulos de estabilização monetária por ele emitidos, para incentivar os investidores a não precipitar a fuga de bolívares. Em setembro, o Banco oferecia rendimentos nos certificados de depósito de 60,1\% para instrumentos de dez dias e com isso matava, efetivamente, o crédito local.

A política monetária restritiva e a taxa de câmbio quase fixada derrotaram com sucesso o ataque especulativo. O Banco puniu severamente aqueles agentes que tomaram bolívares emprestados no país para comprar dólares. Esses agentes viram suas dívidas referenciadas no bolívar sujeitas a taxas de juros altíssimas. Logo os devedores tiveram que vender os mesmos dólares que haviam comprado para poder honrar suas dívidas referenciadas no bolívar. Por volta do fim de setembro, a demanda pelo bolívar recuperou-se e seu valor subiu aos níveis existentes antes da crise.

Embora o Banco Central tivesse vencido a guerra, o campo de batalha estava em ruínas. Ao defender o bolívar, a já prejudicada economia sofreu mais um aperto, tornando a Venezuela um dos piores administradores econômicos latino-americanos em 1998-99 (ver figuras 6.1, 6.2, 6.3 e 6.4). A recessão econômica da Venezuela foi aprofundando-se no último trimestre de 1998, à medida que o déficit fiscal se aproximava de $10 \%$ do Produto Interno Bruto (PIB) e o desemprego atingia o patamar de quase $21,9 \%$ entre os jovens (de 15 a 24 anos de idade). Embora o declínio na demanda agregada e o aumento da incerteza política - mais do que os procedimentos político-econômicos do Banco Central - tivessem causado a enorme recessão de 1998, as políticas restritivas do Banco obstruíram todas as perspectivas de uma rápida recuperação. Porém, claro está que sem essas medidas, a recessão da Venezuela teria sido muito mais acentuada. 
Figura 6.1

Déficit ou Superávit do Setor Público

na Venezuela, 1997-1999 (porcentagem do PIB)

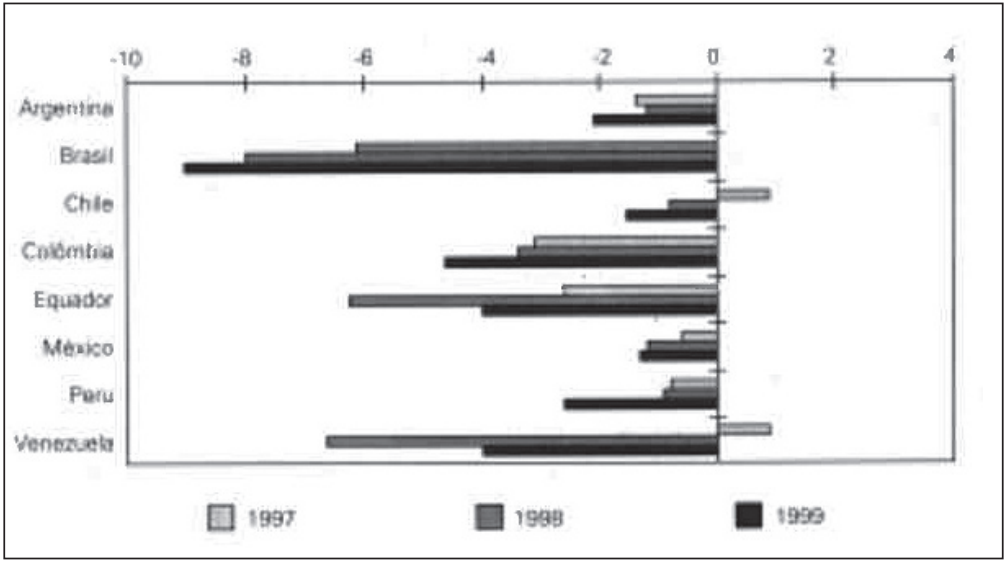

Fonte: CEPAL, baseado em valores oficiais.

1. Números de Déficit/Superávit calculados com base em valores expressos em moeda local e a preços correntes. 2. Valores de 1999 são estimativas preliminares.

Figura 6.2

Desemprego Urbano

na Venezuela, 1997-1999 (taxas anuais médias)

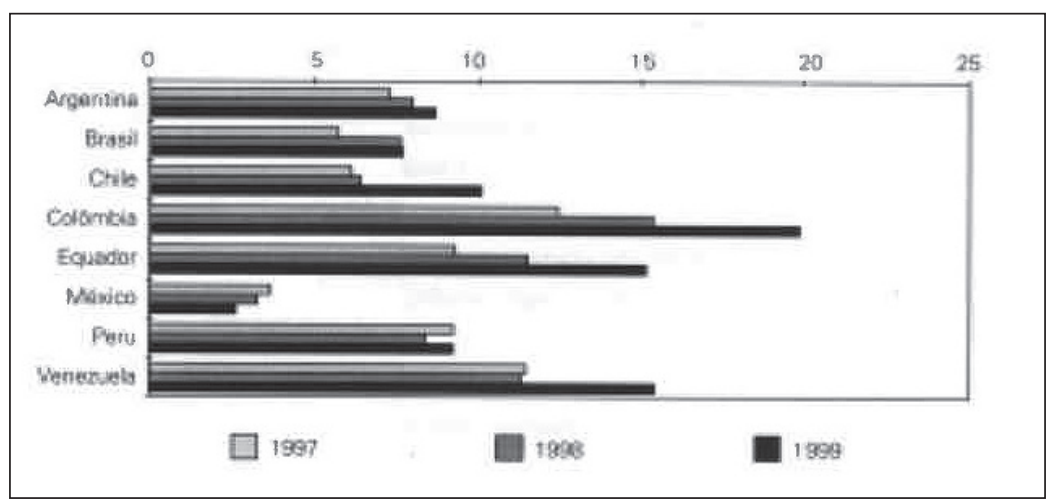

Fonte: CEPAL, baseado em valores oficiais.

1. Brasil: valor de 1999 é uma média de janeiro a outubro. 2. Chile e Colômbia: valores 1999 são uma média dos três primeiros trimestres. 3. Peru: valor de 1999 é relativo à primeira metade do ano. 
Figura 6.3

índice de Preços ao Consumidor na Venezuela, 1997-1999

(variações de dezembro a dezembro)

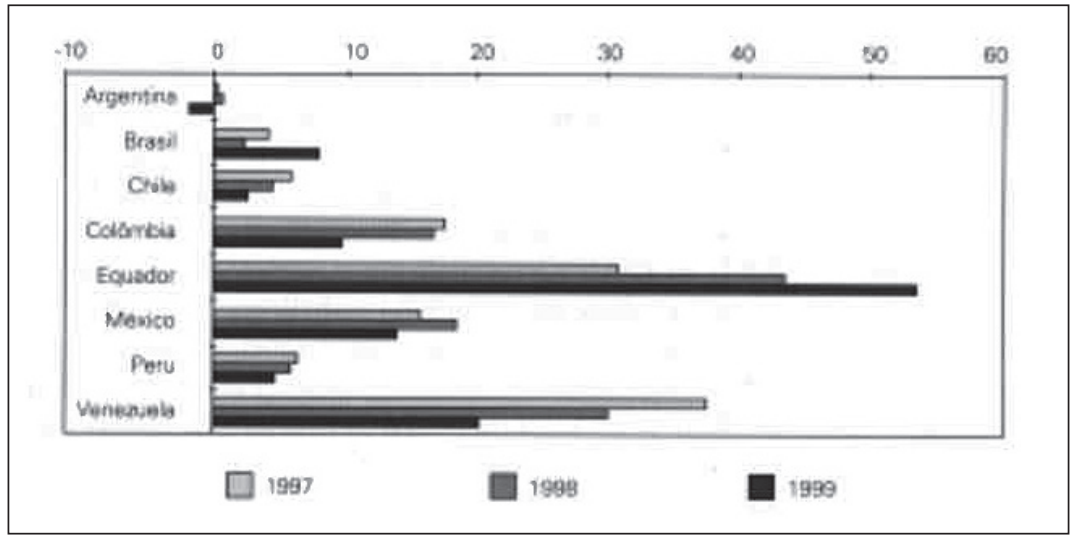

Fonte: CEPAL, baseado em informações oficiais de cada país.

1. Valores de 1999 correspondem 1a variação de preços durante o período de 12 meses entre novembro de 1998 e novembro de 1999.

Figura 6.4

Produto Interno Bruto (PIB) Per Capita na Venezuela, 1997-1999

(porcentagens baseadas em valores a preços de 1995)

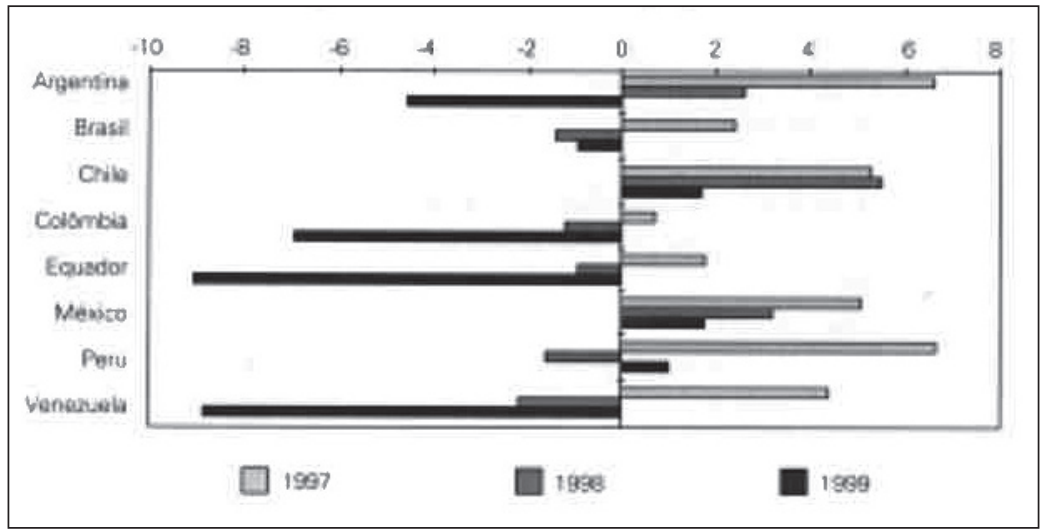

Fonte: CEPAL, baseado em valores oficiais convertidos para dólares a preços constantes de 1995 1. Valores de 1999 são estimativas preliminares. 2. Valores para Colômbia foram estimados pelo ECLAC com base em valores provisórios do National Bureau of Statistics (DANE).

\section{O PADRÃO DA REFORMA NA VENEZUELA: CORTA-RELAXA-QUEBRA}

Embora significativos, os choques externos de 1998 não foram a causa das dificuldades econômicas da Venezuela durante o período de 1997-99. A causa real foi um problema político mais fundamental: o persistente fracasso, nos últimos quinze anos, em se consolidar um programa de reforma econômica. Essa história 
de reformas fracassadas explica por que a Venezuela ficou tão suscetível a esses choques e tão constrangida ao manifestar uma reação.

Até meados da década de 1970, a Venezuela era considerada o país do milagre. Havia alcançado a industrialização, conquistas trabalhistas e surpreendentes melhorias na qualidade de vida, tudo isso sem apresentar aqueles vícios comuns da América Latina, tais como desequilíbrios macroeconômicos (a inflação e as dívidas estavam baixas), instabilidade política (eram pouco os conflitos de classes e partidos) e autoritarismo (os partidos democráticos alternavam-se no poder sem interrupção). No início da década de 80 , entretanto, a Venezuela começou a se parecer menos com um milagre e mais com o resto da América Latina. Especificamente, começou a conhecer dívidas externas crônicas, desequilíbrio macroeconômico, crises nas taxas de câmbio, mercados financeiros retraídos, erosão da vitalidade democrática, falta de adaptação por parte das instituições políticas, enfraquecimento das estruturas estatais e crescente inquietude social e política. ${ }^{11}$

A partir de 1979, quatro administrações eleitas por via democrática e um governo provisório chegaram ao poder com o compromisso de corrigir esses males. Assim, a Venezuela afundou-se cada vez mais naquilo que eu chamo de ciclo de reforma "corta-relaxa-quebra”. Cada ciclo começa com a erupção de uma série de crises econômicas. O governo reage, implementando ajustes duros que impõem graves custos para a sociedade - "corta". As reformas produzem alguns resultados, mas logo perdem o vigor porque são mal administradas ou prematuramente abandonadas - a fase "relaxa". Esse relaxamento culmina numa outra crise econômica - "a quebra"-, preparando o período para um novo round de reformas. Esse ciclo repetiu-se quatro vezes desde 1979 (ver tabela 6.2). Por isso a Venezuela não é um caso em que não se evitou realizar reformas ou implantá-las, mas sim um caso de reformas não consolidadas.

Alberto Alesina e Allan Drazen emitiram o importante argumento de que o fracasso repentino dos esforços para efetuar reformas pode funcionar vantajosamente para os reformadores, porque leva ao atrito por parte dos oponentes. ${ }^{12}$ No entanto, na Venezuela essa história de reformas abortadas complicou, em vez de facilitar, as propostas de recuperação económica: os constantes fracassos deixaram a Venezuela com uma série de problemas não resolvidos e criaram um novo conjunto de problemas específicos de reformas defasadas.

\footnotetext{
${ }^{11}$ Ver Brian F. Crisp e Daniel H. Levine, "Democratizing the Democracy? Crisis and Reform in Venezuela" Journal of Interamerican Studies and Word Affairs, vol. 40 (Verão de 1998), pp. 27-63; Jennifer McCoy e William C. Smith, "From Deconsolidation to Reequilibration? Prospects for Democratic Renewal in Venezuela”, in Jennifer McCoy, Andrés Serbina, William C. Smith, e Andrés Stambouli, orgs., Venezuelan Democracy under Stress (New Brunswick, NJ: Transaction Books, 1995), pp. 237-83; Richard S. Hillman, Democracy for the Privileged: Crisis and Transition in Venezuela (Boulder: Lynne Rienner, 1994 ); Moisés Naím e Ramón Piñango, El caso venezolano: Una ilusión de armonía (Caracas: Ediciones IESA, 1985); e Miriam Kornblith, "Deuda y democracia en Venezuela: los sucesos del 27 y 28 febrero de 1989”, Cuadernos del CENDES, vol. 10 (1989), pp. 17-34.

12 Alberto Alesina e Allan Drazen, "Why Are Stabilizations Delayed?", American Economic Review, vol. 81 (dezembro de 1991), pp. 1.170-88.
} 
Tabela 6.2

O Padrão Corta-Relaxa -Quebra das Reformas Econômicas na Venezuela

\begin{tabular}{|c|c|c|c|}
\hline Administração & Corta & Relaxa & Quebra \\
\hline Luís Herrera Campins (1979-84) & 1979 & $1980-81$ & 1983 \\
\hline Jaime Lusinchi (1984-89) & 1983-85 & 1986-88 & 1988 \\
\hline Carlos A. Pérez (1989-93) & 1989-91 & 1991-92 & 1993-95 \\
\hline \multicolumn{4}{|l|}{ Ramón Velásquez (1993-94)a } \\
\hline Rafael Caldera (1994-99) & 1996 & 1997 & 1998 \\
\hline \multicolumn{4}{|c|}{$\begin{array}{l}\text { Fontes: Para Campíns, Ricardo Hausmann e Gustavo Márquez, "La crisis económica venezolana. Origen, mecanis- } \\
\text { mos y encadenamientos", Investigación Económica. vol } 165 \text { (1983), pp 117-54; e Miguel Rodriguez. "Public Sector } \\
\text { Behavior in Venezuela". in Felipe Larrain e Marcelo Selowsky, orgs. The Public Sector and the Latin American Crisis } \\
\text { (San Francisco: ICS Press. 1991). Para Lusinchi, Ricardo Hausmann. "Venezuela", in John Williamson, org., Latin } \\
\text { American Adjustment: How Much Has Happened? (Washington: Institute for International Economics, 1990). Para } \\
\text { Pérez e Velásquez, Moisés Naím. Paper Tigers and Minotaurs. The Politics of Venezuela's Economic Reforms } \\
\text { (Washington: Carnegie Endowment for International Peace, 19931. Javier Corrales, "Presidents, Ruling Parties, and } \\
\text { Party Rules: A Theory on the Politics of Economic Reform in Latin America", in Comparative Politics. vol } 32 \text { (2000), } \\
\text { pp 127-50. Aníbal Romero, "Rearranging the Deck Chairs on the Titanic: The Agony of Democracy in Venezuela", in } \\
\text { Latin American Research Review, vol 32, n. } 1 \text { (1997). pp. 7-36; Jennifer McCoy and William C Smith, "From Decon- } \\
\text { solidation to Reequibration? Prospects for Democratic Renewal in Venezuela", in Jennifer McCoy et al.orgs.. Ven- } \\
\text { ezuelan Democracy under Stress (New Brunswick, N.J.: Transaction Books. 1995); e Juan Carlos Navarro, "The } \\
\text { Reversal of Fortune: The Ephemeral Success of Adjustment in Venezuela between } 1989 \text { e 1993," mimeo. World } \\
\text { Bank Project on Governance and Successful Adjustment. Caracas, November 1994. Para Caldera, Corrales, "Pres- } \\
\text { idents, Ruling Parties, and Party Rules," and Pedro Palma. "La economia venezolana en el quinquenio 1994 -1998 } \\
\text { - de una crisis a otra," in Nueva Economia } 8 \text { (Abril 1999). pp- 97-158. }\end{array}$} \\
\hline
\end{tabular}

a) O presidente interino Velásquez introduziu grandes reformas econômicas, mas seu mandato foi muito curto (me nos de seis meses) para que ele implementasse todas, e seu sucessor reverteu muitas daquelas que tinham sido introduzidas.

\section{Problemas Herdados e Não Resolvidos}

Alguns destes problemas são típicos do período pré-reformas da América Latina: inflação crônica que não ficava abaixo de $30 \%$ entre o fim dos anos 80 e o ano de 1997; um déficit fiscal estrutural, apesar dos cortes contínuos nos gastos durante a década de 90; escassas receitas fiscais, sem contar o petróleo; um distorcido sistema de impostos cronicamente insuficiente e repleto de isenções; serviços públicos sem verbas e ineficazes. Além disso, alguns setores, como o de energia elétrica, o farmacêutico e o agrícola, ainda eram controlados por leis obscuras que perpetuavam as barreiras para os investimentos. O setor privado não-petroleiro não é diversificado, muito menos competitivo, tornando-se suspeito para o investimento, exceto em conjunção com um suporte fiscal do Estado. Os níveis de pobreza e de má qualidade de vida, sempre altos, continuaram a deteriorar-se continuamente na década de 90. Em 1997 os salários eram cerca de 60\% mais baixos 
do que em 1978. ${ }^{13}$ Outro problema não resolvido é o mecanismo embutido nas políticas fiscais pró-cíclicas. A política fiscal tende a ser altamente pró-cíclica na maior parte da América Latina. ${ }^{14}$ Mas na Venezuela esse problema foi mais acentuado devido à sua condição de petro-Estado. ${ }^{15}$ Durante os booms do petróleo, a economia automaticamente se expande (devido aos níveis de produção mais elevados do PDVSA), bem como as receitas fiscais. O aumento das receitas fiscais aciona, de modo inevitável, o gasto descontrolado, além de estimular a demanda agregada. Quando os preços do petróleo baixam, a atividade econômica se retrai (pois o PDVSA retarda a produção), assim como as receitas fiscais, que levam a cortes que, por sua vez, exacerbam a desaceleração econômica. Além do mais, a perpétua determinação do governo de manter uma taxa de câmbio supervalorizada gera taxas de juros mais elevadas e, por conseguinte, maiores gastos no serviço da dívida. Assim, o padrão continua até a situação tornar-se insustentável e o governo se ver forçado a assumir uma desvalorização maciça. ${ }^{16}$

Essa acentuada pro pensão pró-cíclica das finanças públicas aponta para a forte necessidade de um mecanismo gerador de poupanças durante períodos de boom econômico. Até 1998, nenhum programa de reforma havia desenvolvido esse mecanismo. Isso revela outro sinal de fraqueza, bem como prejuízos de todos os esforços para reformas anteriores.

\section{Novos Obstáculos}

Alguns dos problemas econômicos da Venezuela ao fim da década de 90 foram típicos não só da América Latina, mas também de países de reformas defasadas. Um problema comum das nações - que de maneira repetida tentam, mas fracassam - no implante de reformas é a emergência de uma configuração institucional assimétrica. Um resultado dos ciclos "corta-relaxa-quebra" é que algumas instituições econômicas e normas se modernizaram enquanto outras permaneceram totalmente sem reforma. Isso ajuda a explicar algumas discrepâncias nos resultados das políticas implementadas. Por exemplo, o livre-comércio avançou nos setores de manufaturados, mas sofreu dificuldades na agricultura. ${ }^{17} \mathrm{O}$ país estava bem integrado na economia internacional, mas não possuía mecanismos para lidar com a volatilidade externa. Havia total abertura para os investimentos estrangeiros, mas

\footnotetext{
13 Pedro Palma, "La economía venezolana en el quinquenio 1994-1998: de una crisis a outra", Nueva Economía, vol. 8 (abril de 1999), pp. 97-158.

${ }^{14}$ Michael Gavin e Roberto Perotti, "Fiscal Policy in Latin America “, in Ben S. Bernanke e Julio Rotemberg, orgs., NBER Macroeconomics Annual 1997 (Cambridge: MIT Press, 1997).

15 Terry Lynn Karl, “The Venezuelan Petro-State and the Crisis of 'Its' Democracy”, in McCoy, Serbin, Smith e Stambouli, orgs., Venezuelan Democracy under Stress, pp. 33-55.

${ }^{16}$ Congreso de la República, Informe de coyuntura.

17 Javier Corrales e Imelda Cisneros, "Corporatism, Trade Liberalization, and Sectoral Responses: The Case of Venezuela, 1989-1999”, World Development, vol. 27 (dezembro de 1999), pp. 2.099-122.
} 
vários setores econômicos permaneciam contaminados por normas obscuras que não os incentivavam. O Banco Central era bem autônomo, mas o Ministério das Finanças continuava suscetível às pressões dos lobbies. Em suma, tanto os setores reformados quanto os não reformados e as instituições estatais coexistiam com dificuldade.

Talvez a principal consequência do padrão "corta-relaxa-quebra" tenha sido a erosão da credibilidade do Estado, dos políticos e das propostas das reformas. ${ }^{18}$ Isso ficou evidente tanto entre os agentes econômicos proeminentes, como entre os líderes do empresariado e o público em geral. Este último concluiu, baseado na experiência real, que era mais provável que o governo falhasse em seus compromissos de reformas do que os honrasse. Assim, comportou-se de acordo, recusando-se a cooperar com quaisquer medidas do governo. $\mathrm{O}$ repetido fracasso das reformas também assegurou a continuação e possivelmente o aumento da oposição às reformas entre o público geral. $\mathrm{O}$ fato de nenhum programa de reforma produzir alguma correção duradoura permitiu o fortalecimento dos opositores e não o contrário. Os opositores das reformas conseguiram argumentar, sem fundamento, porém de forma convincente, que os males da Venezuela foram causados pelos planos anunciados, evitando, convenientemente, fazer o real diagnóstico de que os males foram o resultado do fracasso na manutenção de tais reformas.

Isso obscureceu a credibilidade dos esforços para efetuar as reformas. Os cidadãos comuns chegaram a equacionar "ajuste", uma palavra que ouviam há vinte anos, com a palavra "sacrifício", nada obtendo em troca. Isso era mais um golpe que os políticos corruptos deram, ao preço do ajuste dos cidadãos, com o intuito de bagunçar os procedimentos. A tabela 6.3 mostra os níveis violentamente baixos da confiança pública nos ministros e políticos. Dado que estes são os "autores" das reformas, esses baixos índices de confiança revelam a extensão da falta de credibilidade nas autoridades do governo até 1998 . Tudo isso foi o resultado de vinte anos de ciclos repetidos de "corta-relaxa-quebra".

\section{O Último Round de Reformas na Venezuela: A “Agenda Venezuela”}

O mais recente round de reformas voltadas para o mercado da Venezuela, a Agenda Venezuela (1996-98), caiu no mesmo ciclo corta-relaxa-quebra. Como algumas tentativas prévias, inicialmente fez grandes progressos. Por exemplo, tirou a Venezuela de um de seus mais sinistros períodos econômicos (1994-96), quando o Estado administrou mal uma crise financeira através da implantação de bailouts econômicos (assistências financeiras de emergência) inconsistentes e não transparentes. No fim, a soma total dos bailouts econômicos era de $15 \%$ do PIB, um dos

\footnotetext{
${ }^{18}$ Para o impacto dos déficits sobre as relações Estado-sociedade durante os processos de reforma, ver Dani Rodrik, “Promises, Promises: Credible Policy Reform via Signaling”, Economic Journal, vol. 99 (1989), pp. 756-72.
} 


\begin{tabular}{lc}
\hline Profissão & Respostas expressando confiança, porcentagem \\
\hline Professor universitário & 77 \\
Médico & 75 \\
Professor & 70 \\
Âncora de Telejornal & 68 \\
Jornalista & 56 \\
Pesquisador de Opinião & 54 \\
Juiz & 29 \\
Oficial de Polícia & 21 \\
Líder de Sindicato & 17 \\
Funcionário Público & 17 \\
Político & 10 \\
Ministro de Gabinete & 9 \\
\hline
\end{tabular}

Fonte: Consultores 21, "Insight 21", VenEconomv Monthly, vol 16 (dezembro de 1998), p. 9.

mais onerosos bailouts estatais jamais vistos. ${ }^{19}$ A Agenda Venezuela também abriu o setor petroleiro para investimentos estrangeiros diretos (a tão decantada apertura petrolera). Investidores internacionais reagiram trazendo o capital de volta ao país. Todavia, a Agenda Venezuela logo caiu no modo de relaxamento habitual. Algumas reformas macro e microeconômicas foram implantadas em 1997. Privatização, desregulamentação, reformas de impostos, reforma fiscal e reformas nos serviços civis foram tímidas. Os salários no setor público não foram mantidos sob controle. Uma proposta legislativa para a criação do Fondo de Estabilización Macroeconómica, que teria reagido à natureza pró-cíclica da administração econômica e que teria ajudado a salvar alguns dos $\$ 6$ a $\$ 8$ bilhões nas quedas do petróleo ocorridas em 1997, ficou parada no Congresso a maior parte de 1997.

Além disso, a Agenda Venezuela, como algumas tentativas de reformas precedentes, gerou novos problemas. Dentre eles, o mais proeminente foi a dominação contínua do petróleo, em detrimento dos setores não-petroleiros. Como parte da apertura petrolera, o governo concordou em financiar uma expansão do PDVSA por dez anos, e que dobraria a capacidade de produção de petróleo para 6,4 milhões de barris por dia, um investimento total de $\$ 65$ bilhões. A administração cometeu o mesmo erro dos anos 70, que consistia em abusar de investimentos subsidiados pelo petróleo para resolver um desequilíbrio fiscal. O progresso feito

\footnotetext{
${ }^{19}$ Ver Gustavo García, com Rafael Rodríguez e Sílvia Salvato, Lecciones de la crisis bancaria de Venezuela (Caracas: Ediciones IESA, 1998).
} 
desde 1990 na diversificação da economia sofreu um revés: depois de cair de $19 \%$ em 1990 para quase 7\% em 1995, a participação das rendas advindas do petróleo sobre as contas públicas teve um retrocesso de $14 \%$ por volta de 1997 . Além do mais, a maciça presença estatal no setor petroleiro excluiu os investimentos privados, como ficou evidenciado pela retração destes de 1993 a 1997.

\section{Os Obstáculos Políticos da Agenda Venezuela}

Por que a Agenda Venezuela repetiu as fases relaxa-quebra dos esforços precedentes de reformas? Alguns analistas culpam o boom do petróleo de 1997 por presumivelmente ter diminuído a urgência dos reformadores de continuar com a sua missão. ${ }^{20}$ Alguns culpam a hesitação pessoal - ou embaraço - do presidente Caldera, que assumiu o poder em 1994 denunciando fortemente as reformas de mercado do começo dos anos 90 e que gastou seus primeiros dois anos no poder desmantelando-as. Então Caldera interrompeu as reformas de mercado em 1996 - depois de arruinar a economia com políticas estatais. Mas muitos argumentam que ele não era nem um verdadeiro convertido nem humilde o bastante para aceitar que estava errado - daí sua hesitação em implantar reformas de mercado em 1997. No entanto, muitos policy makers afirmam que nem o boom do petróleo nem o presidente tiveram qualquer impacto desse tipo. O czar da reforma Teodoro Petkoff na verdade via o boom do petróleo como uma bem-vinda escora - uma oportunidade para seguir em frente, em vez de relaxar as reformas. ${ }^{21}$ Ademais, os reformistas também argumentam que embora Caldera nunca tenha sido imensamente entusiástico, ele nunca apresentou quaisquer obstáculos aos programas de reformas propostos pelos membros do gabinete civil. Por isso, nem o petróleo nem a hesitação presidencial explicam o fracasso da Agenda Venezuela.

A mais importante razão pela qual a Agenda Venezuela entrou numa fase de relaxamento foi a mesma dos ciclos de reformas precedentes: desavenças nas relações entre o Estado e os partidos políticos. No começo dos anos 80, o forte sistema de partidos da Venezuela começou a decair.22 $\mathrm{O}$ problema não era que os partidos

\footnotetext{
${ }^{20}$ Ver Palma, "La economía venezolana “. Muitos economistas políticos estão convencidos de que os petroEstados em geral são inerentemente deficientes quando começam a introduzir reformas que recorrem à volatilidade associada aos booms e fracassos do petróleo. Contudo, alguns petro-Estados administram os ciclos do petróleo melhor do que outros, sugerindo que fatores políticos, a exemplo das características do Estado, mais do que a dependência do petróleo, determinam como as nações enfrentam essa " maldição de recursos". Para uma excelente revisão dessas questões, ver Michael L. Ross, "The Political Economy of the Resource Curse”, World Politics, vol. 51 (janeiro de 1999), pp. 297-322.

${ }^{21}$ Teodoro Petkoff (ministro do Planejamento (Cordiplan) durante a Agenda Venezuela), entrevistado pelo autor em Caracas, agosto de 1999.

22 Ver Michael Coppedge, "Prospects for Democratic Governability in Venezuela", Journal of Interamerican Studies and World Affairs, vol. 36 (verão de 1994 ), pp. 39-64; Miriam Kornblith e Daniel H. Levine, "The Life and Times of the Party System", in Scott Mainwaring e Timothy Scully, orgs., Building Democratic Institutions: Parties and Party Systems in Latin America (Stan ord University Press,
} 
dominantes estavam desaparecendo, mas sim que eles se estavam tornando cada vez mais fechados a novas lideranças e iniciativas. Por conseguinte, seu nível de apoio declinou com constância, como atestam os níveis de lealdade partidária, as taxas de abstenção eleitoral, a desconfiança em relação aos políticos e o apoio da opinião pública à tentativa de golpe de fevereiro de $1992 .{ }^{23}$ As regras internas dos partidos, que isentavam os líderes partidários de ter de competir eleitoralmente com o intuito de ganhar posições de liderança, impedia o rodízio dos mesmos. Por isso, a liderança partidária permaneceu virtualmente imutável, mesmo quando os partidos sofriam revezes nas eleições. Isso distinguiu os maiores partidos venezuelanos do partido-líder do México, o Partido Revolucionário Institucional (PRI), que, embora menos democrático historicamente, sempre passou pelo rodízio de líderes em cada nova administração. ${ }^{24}$ Essa separação entre um eleitorado cada vez mais desiludido e a rigidez dentro dos partidos, que impediu o rodízio de liderança e ideias, foi a origem das reformas trabalhistas da Venezuela. Sob condições de insatisfação social e crises econômicas persistentes, os partidos políticos menos rígidos talvez quisessem passar por transformações internas. Mas na Venezuela, os antigos líderes partidários continuaram entrincheirados, garantindo, essencialmente, a continuidade de ideias ultrapassadas. Esses líderes entrincheirados reagiram aos declínios do apoio da sociedade não adaptando suas ideais, mas recorrendo a fórmulas ultrapassadas, a saber: recorrendo a apelos populistas. Agiram em cima da errônea suposição de que os votos poderiam ser recuperados através das doações tradicionais, de base corporativa, em vez de demonstrar competência na resolução das crises das medidas político-econômicas. Era difícil para os indivíduos que se interessassem em seguir uma estratégia diferente obter posições de liderança nos partidos dominantes.

Por volta de 1993, o sentimento antipartidário atingiu o ápice. Caldera capitalizou sobre esse sentimento fazendo uma aliança entre um pequeno partido de esquerda (Movimiento al Socialismo, ou MAS) e uma coalizão de última hora dos partidos e forças nacionalistas independentes de esquerda (Convergencia). A medida foi uma estratégia eleitoral bem-sucedida, mas uma terrível receita para a governabilidade. Essa fórmula eleitoral deu a Caldera uma base governista a um só

1995 ), pp. 37-71; José E. Molina e Carmen Pérez, "Evolution of the Party System in Venezuela, 19461993", Journal of Interamerican Studies and World Affairs, vol. 40 (verão de 1998), pp. 1-26; Ángel Eduardo Álvarez, "La crisis de hegemonía de los partidos políticos venezolanos", in Ángel E. Álvarez, org., El sistema político venezolano: crisis y transformaciones (Caracas: Universidad Central de Venezuela, Instituto de Estudios Políticos, 1996); e Crispe Levine, "Democratizing the Democracy".

${ }^{23}$ Enrique A. Baloyra, "Deepening Democracy with Dominant Parties and Presidentialism: The Venezuelan Regime in a Period of Turbulence", in Kurt von Mettenheim e James Malloy, orgs., Deepening Democracy in Latin America (University of Pittsburgh Press, 1998), pp. 38-54.

${ }^{24}$ Javier Corrales, "El Presidente y su gente: Conflicto y cooperación en los âmbitos técnico y político en Venezuela, 1989-1993”, Nueva Sociedad, vol. 152 (novembro-dezembro de 1997), pp. 93-107. 
tempo fraca e fragmentada (Convergencia-MAS ficou em terceiro lugar no Congresso, e o MAS começou a rachar depois do anúncio da Agenda Venezuela).

Dois grandes males relacionados aos partidos políticos convergiram durante a Administração Caldera: a tendência de tanto o partido de situação quanto de oposição apegarem-se a antigos líderes e consequentemente a velhas fórmulas, e a tendência de cisão no partido da situação quanto à política econômica. Esse último problema esmagou a administração Pérez, na medida em que setores de seu próprio partido dominante, Acción Democrática $(\mathrm{AD})$, repudiavam suas reformas e, por conseguinte, seu governo. ${ }^{25}$ Caldera, no entanto, também se tornou vítima de uma mudança similar nas relações entre os partidos dominantes no Executivo: em 1998, a Convergencia essencialmente se desintegrou e o MAS desertou para as fileiras de Hugo Chávez.

Com essas dificuldades no nível partidário, até o mais capaz e o maior idealizador "tecnopolítico" de reformas teria dificuldades para implantá-las. Alguns ecos de propostas de reformas encontraram virulenta oposição por parte da coalizão dominante e dos partidos de oposição afins. Caldera tentou conseguir o apoio dos muitos e mesmos partidos tradicionais para os quais havia feiro campanha contra -AD e o Partido Social Cristão, COPEI - mas eles venderam seu apoio a um preço muito alto. Tipicamente aprovavam as reformas só quando recebiam importantes concessões - o que, definitivamente, atrasou as reformas. Por exemplo, os partidos de oposição concordaram com a apertura petrolera somente em troca de $116 \%$ de aumento no salário dos trabalhadores do setor petroleiro - muitos dos quais eram membros das uniões dominadas pela AD. Essa concessão foi retirada quando se confrontou com as metas inflacionárias anunciadas pelo Banco Central. ${ }^{26} \mathrm{Em}$ agosto de 1998, quando se deram os choques, mais de cinquenta projetos de reformas-chave encalharam no Congresso, inclusive o crucial Fondo de Estabilización Macroeconómica. ${ }^{27}$

Divergências no nível dos partidos políticos - isto é, a força repressora das antigas elites partidárias apesar das significativas mudanças socioeconômicas - assim explicam o repetido ciclo de corta-relaxa-quebra na Venezuela, bem corno sua suscetibilidade aos choques de 1998. A Venezuela começou 1998 com uma agenda de reformas estruturais pendentes, inclusive algumas reformas de mercado básicas e de primeira geração (racionalização e desregulamentação fiscal, por exemplo), bem como com um cenário de reformas especificamente venezuelanas (por exemplo, o Fondo de Estabilización Macroeconómica). Além disso, a Agenda Venezuela gerou seu próprio conjunto de problemas específicos, dando maior apoio ao petróleo,

\footnotetext{
${ }^{25}$ Javier Corrales, "Presidents, Ruling Parties, and Party Rules: A Theory on the Politics of Economic Reform in Latin America”, Comparative Poliics, vol. 32 (janeiro de 2000), pp. 127-50.

${ }^{26}$ Perkoff, entrevista.

${ }^{27}$ Herbert Koeneke, “Congressional Report Card: A Failure, and Little to Learn From”, VenEconomy Monthy, vol. 15 (setembro de 1998), pp. 15-6.
} 
o que aumentou, desnecessariamente, o impacto da queda do preço do petróleo de 1998. O problema da credibilidade no Estado e nos políticos atingiu, porém, outro ápice. Compreensivelmente, os agentes econômicos perderam toda a confiança na capacidade do governo de fazer o que se esperava. Setores populares, por sua vez, estavam simplesmente fartos dos esforços de reformas que nunca davam certo. Daí o fato de o mais anti-reformista, antipartidário candidato presidencial de 1998, Hugo Chávez, ter chegado ao topo nas eleições, infundindo, sucessivamente, novos níveis de incerteza interna e externamente. Tudo isso era a consequência direta do ciclo de corta-relaxa-quebra dos esforços de reformas.

\section{A REAÇÃO DO ESTADO: O BANCO CENTRAL COMO SALVAÇÃO}

Uma vez ocorridos os choques, a Venezuela se confrontou com duas opções de políticas econômicas: anunciar um pacote baseado na desvalorização junto com reformas estruturais mais profundas (a solução do FMI), ou simplesmente defender o bolívar. O fundo da questão era a necessidade de decidir entre ir ao encontro de um regime de taxas de câmbio mais flexível - nas pegadas dos artífices políticos mexicanos e brasileiros - ou defender o regime de taxa de câmbio quase-fixada existente.

Desde os anos 80, a Venezuela vem passando por todos os tipos de regimes de taxas de câmbio: taxas de câmbio múltiplas, controladas (1983-88); taxas de câmbio livres, porém estáveis (1989-92); crawling peg rates (bandas cambiais) (199294); e taxas de câmbio fixas e controladas (1994-96). ${ }^{28}$ Que Caldera quisesse estabelecer controles sobre as taxas de câmbio em 1994-96 era surpreendente, dada a horrível experiência da Venezuela com controles desse tipo nos anos $80 .{ }^{29}$ Realmente, os controles da taxa de câmbio durante 1994-96 reproduziram algumas das mesmas distorções originadas dos controles da taxa de câmbio durante os anos 80: taxas de juros reais negativas, mercados monetários negros, declínio das reservas, acúmulo de responsabilidades pelo Banco Central, fuga de capitais e aumento da inflação (que chegou a quase $150 \%$ no começo de 1996). ${ }^{30}$

Logo depois que a Agenda Venezuela foi implantada, o governo permitiu que a taxa de câmbio flutuasse por alguns meses para demonstrar a volta da liberdade econômica. Após testar o real valor do bolívar, o Banco Central ancorou a taxa de câmbio em meados de 96, entrando, assim, num sistema de taxa de câmbio "alta-

\footnotetext{
${ }^{28}$ José Guerra, “Síntesis de la política cambiaria de Venezuela”, Monetaria. vol. 20 (janeiro -março de 1997), pp. 95-115.

${ }^{29}$ Ver Guerra, “Síntesis”; e Agustín Beroes, RECADI: La gran estafa. (Caracas: Planeta, 1990).

${ }^{30}$ Banco Central de Venezuela (BCV), 1998 Year-End Address, President of the Central Bank of Venezuela (Caracas: 1998); e Herbert Koeneke, "Bad Balance for Caldera Administration”, VenEconomy Monthly, vol. 16 (janeiro de 1999), pp. 3-6.
} 
mente controlado", baseado em bandas e numa antevista taxa de desvalorização (paridad central). A taxa de desvalorização mudou de acordo com um conjunto de porcentagem mensal bem abaixo das taxas de inflação. Por isso, a taxa de câmbio se tornou uma arma de combate à inflação ou, mais especificamente, ao desregrado desperdício fiscal. ${ }^{31}$ Porque o governo se mostrou incapaz de controlar os gastos fiscais, o próprio Banco Central chamou a responsabilidade a si, absorvendo ele próprio as pressões inflacionárias através da manutenção do preço dos dólares baixo. As bandas foram estabelecidas em mais ou menos 7,5\% da paridade internacional, e foram feitas promessas de que a taxa de câmbio nunca poderia ultrapassar essas bandas.

Embora tecnicamente fosse um regime de taxa de câmbio livre, na realidade o sistema era o de uma taxa de câmbio quase-fixada. Devido ao quase monopólio do Estado venezuelano (através do Banco Central) na oferta de câmbio (responsável por $85 \%$ das exportações), o mesmo tinha grande poder para determinar a taxa de câmbio real. ${ }^{32} \mathrm{Em}$ 1997, o Banco Central usou seu poder para garantir que a taxa de câmbio permanecesse relativamente baixa. Na realidade, o Banco baixou a paridade central três vezes (em janeiro, julho e dezembro) e chegou até mesmo a baixar a taxa de desvalorização para 1997. Um dos resultados foi que a inflação anual caiu de 112,3\% em 1996 para 17,3\% no fim de 1997. Isso provocou uma sensação de triunfo entre a equipe do Banco Central.

Os choques de 1998 puseram um fim no humor otimista. A demanda de dólares subiu vertiginosamente, empurrando a taxa de câmbio de 504 bolívares por dólar norte-americano em dezembro de 1997 para 582 bolívares por dólar no fim de agosto de 1998, ultrapassando em muito a meta da taxa de desvalorização fixada pelo Banco (ver figura 6.5). O governo se confrontou com a seguinte questão político-econômica: ou desvalorizava ou vendia dólares suficientes para prevenir uma desvalorização. Na teoria econômica, a flexibilidade da taxa de câmbio é vista como uma política mais apropriada para lidar com choques monetários externos, enquanto uma taxa de câmbio fixa é considerada mais apropriada para choques monetários internos. ${ }^{33} \mathrm{O}$ problema foi que a Venezuela estava passando por ambos os choques, simultaneamente. Por isso, a teoria ajudou muito pouco.

\footnotetext{
${ }^{31}$ Antonio Casas-Gonzáles, "Política monetaria y cambiaria en Venezuela”, trabalho apresentado no seminário Venezuela Competitiva, Embaixada da Venezuela, Santiago, Chile, dezembro de 1997.

32 Roberto Bottome, “Foreign Exchange Markets: Not So Free”, VenEconomy Monthly, vol. 15 (março de 1998), pp. 12-3.

${ }^{33}$ Beth V. Yarbrought e Robert M. Yarbrough, The World Economy: Trade and Finance, quarta edição (Fort Worth: Dryden Press, 1997).
} 


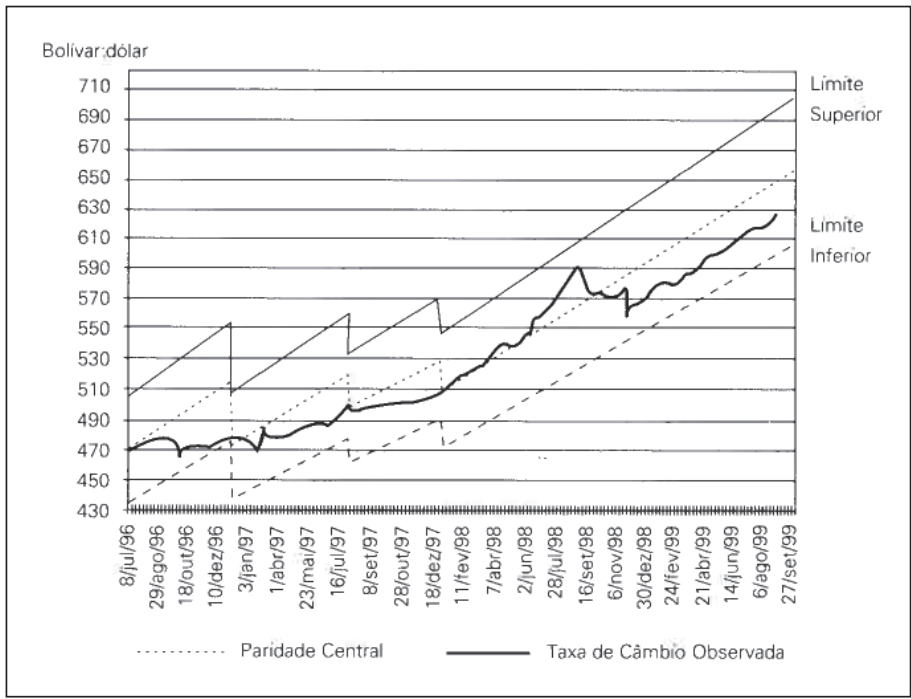

Fonte: Metroeconómica (Caracas).

O FMI recomendou a desvalorização junto com reformas, na esperança de que essa opção pudesse atingir as fontes econômicas e políticas da crise. ${ }^{34}$ Muitos economistas e personalidades influentes (PDVSA, especuladores, exportadores, candidatos a presidente, analistas de políticas econômicas) apoiaram a recomendação do FMI. Tais personalidades reiteraram em reuniões públicas que a moeda tinha sido supervalorizada, legitimando a necessidade de desvalorização. Todavia, o governo rejeitou essa opção, escolhendo, em vez disso, defender o bolívar. Por quê? A resposta tem a ver com três situações: (1) os custos e benefícios esperados de cada política econômica; (2) a busca de credibilidade; e (3) as consequências do fracasso de cada medida (ver tabela 6.4).

\section{Custos e Benefícios Esperados}

Os economistas políticos geralmente sustentam que os governos costumam evitar políticas que geram custos concentrados - isto é, políticas cujos custos recaem direta e intensamente sobre um grupo concentrado de atores. ${ }^{35}$ Evitar a desvalorização de certa forma contradiz esse argumento. Se bem-sucedida, a defesa da moeda contra um ataque especulativo impõe prejuízos concentrados aos especuladores monetários internos, que perdem grandes somas quando percebem que seus

\footnotetext{
34 Antonio Casas-Gonzáles, então presidente do Banco Central, entrevistado pelo autor, Caracas, 4 de agosto de 1999.

35 James Q. Wilson, Political Organizations (Basic Books, 1973).
} 
Tabela 6.4

Desvalorizar ou Não Desvalorizar, 1998

\begin{tabular}{|c|c|c|c|}
\hline Ação & Benefícios & Custos & $\begin{array}{l}\text { Detalhes do } \\
\text { pior cenário }\end{array}$ \\
\hline $\begin{array}{l}\text { Não } \\
\text { desvalorizar }\end{array}$ & $\begin{array}{l}\text { Contém a crise; } \\
\text { assinala credibilidade; } \\
\text { mantém a inflação } \\
\text { sobre controle. }\end{array}$ & $\begin{array}{l}\text { Especuladores penalizados; } \\
\text { exportadores fora do se- } \\
\text { tor petro-lífero perdem } \\
\text { competitividade; recessão } \\
\text { econõmica aprofunda-se } \\
\text { (dois últimos custos po- } \\
\text { dem ser passados para a } \\
\text { próxima administração). }\end{array}$ & $\begin{array}{l}\text { Médio para Baixo: } \\
\text { banco central tem } \\
\text { dotações institucio- } \\
\text { nais para enfrentar } \\
\text { a crise - reservas, } \\
\text { quase - monopólio, } \\
\text { independência legal e real, } \\
\text { histórico de consistência } \\
\text { nas políticas. }\end{array}$ \\
\hline Desvalorizar & $\begin{array}{l}\text { Impacto mínimo } \\
\text { nas finanças públicas, } \\
\text { reduz a supervaloriza- } \\
\text { ção; apoio aos expor- } \\
\text { tadores, especulado- } \\
\text { res lucram. }\end{array}$ & $\begin{array}{l}\text { Inflação mais alta, } \\
\text { espec1almen-te nos bens } \\
\text { de consumo, afetando } \\
\text { grupos de baixa renda, } \\
\text { deterioração das outras } \\
\text { variáveis macroeconômicas; } \\
\text { crescem expectativas de } \\
\text { déficit }\end{array}$ & $\begin{array}{l}\text { Alto: dada a alta } \\
\text { incerteza política e } \\
\text { pobre credibilidade } \\
\text { fiscal, desvalorização } \\
\text { automaticamente } \\
\text { aumenta as suspeitas de } \\
\text { que o governo perdeu o } \\
\text { controle }\end{array}$ \\
\hline
\end{tabular}

novos ativos (dólares) não serão valorizados. Por isso, na política de escolha da taxa de câmbio, os governos levam em consideração mais do que apenas o custo da concentração de custos. Também levam em consideração os benefícios esperados.

As autoridades venezuelanas julgavam que os benefícios econômicos de uma desvalorização eram mínimos. No passado, uma desvalorização do bolívar teria tido um impacto positivo imediato sobre o déficit fiscal: teria permitido que o PDVSA obtivesse mais bolívares para seus dólares, o que aumentaria o imposto sobre as contribuições do PDVSA, porque essas contribuições se baseavam em ganhos convertidos em bolívares. Esse benefício não era mais plausível depois de 1996, porque o serviço da dívida externa era alto o suficiente para compensar quaisquer ganhos das contribuições do PDVSA.

Em contraste, os custos econômicos e políticos da desvalorização somados a reformas eram considerados excessivos. Economicamente, o governo julgava que uma desvalorização desencadearia um "choque inflacionário" repentino devido aos altos preços das importações, e isso era considerado inaceitável. ${ }^{36}$ Uma das consequências da liberação comercial da Venezuela em 1989 foi que as importações se tornaram um componente predominante do consumo interno. Com o automático aumento do preço das importações, um a desvalorização daria um golpe imediato no poder de compra dos cidadãos comuns.

O governo entendeu os custos da defesa da moeda - aprofundamento da re-

\footnotetext{
36 Ver entrevista com Teodoro Petkoff in César Miguel Rondón, País de Estreno: 37 entrevistas antes que el destino del país nos alcance (Caracas: Los Libros de El Nacional, 1998), p. 255.
} 
cessão e posterior erosão da competitividade do setor não-petroleiro. Mas os ideólogos de políticas econômicas julgaram que esses problemas já existiam no começo de 1998, e por isso a defesa do bolívar "seria acrescentada à lista de problemas da Venezuela" ${ }^{37}$ Além disso, dado que a administração estava no fim e que não havia nenhum candidato a presidente para as eleições a caminho, o governo teve, por isso, poucos incentivos para ser altruísta com a próxima administração. E, enquanto os principais perdedores de uma desvalorização seriam as pessoas de baixa renda que teriam que se confrontar com aumentos imediatos de preços, os principais perdedores no âmbito da continuidade da política econômica foram os especuladores, que tinham apostado contra o bolívar, e que não seriam decisivos nas eleições. O governo tinha pouco interesse em aumentar sua popularidade com os especuladores.

\section{Ganhos em Credibilidade}

Talvez mais importante do que as questões de custos e benefícios tenham sido as questões de credibilidade. Uma nova corrente da economia política sugere que os governos se esforçam por sinalizar credibilidade como meio para obter cooperação setorial para políticas públicas. Isto é, os governos tentam convencer os agentes econômicos de que não serão discricionários na elaboração de políticas econômicas para violar promessas em troca de vantagens a curto prazo. ${ }^{38}$ Dado que o esforço por reformas entrou numa outra fase de " relaxamento" em 1997, o governo julgou corretamente que o déficit da sua credibilidade era acentuado. $\mathrm{O}$ governo tinha que reduzir, ou pelo menos conter, o déficit de sua credibilidade. Uma desvalorização, em essência uma quebra no regime de taxa de câmbio, teria erodido ainda mais a sua credibilidade. O regime de taxa de câmbio foi exemplar na continuidade da política econômica desde meados de 1996, a única promessa que o governo cumpriu. Por haver quebrado tantas outras promessas, o governo não podia enfrentar mais um round de negligências.

Lawrence Broz recentemente sustentou que em contextos de tímida tomada de decisões públicas (isto é, quando os agentes não conseguem facilmente discernir e precisar punições para casos em que as regras são quebradas), os governos geralmente optam por uma taxa de câmbio fixada como mecanismo para sinalizar credibilidade. ${ }^{39}$ Isso não é devido ao fato de as taxas de câmbio fixas serem economicamente eficientes - não são - mas porque são altamente transparentes: as pes-

\footnotetext{
37 Petkoff, entrevista.

38 Para um a discussão da importância de sinalizar o compromisso de reforma, ver Rodrik, "Promises, Promises”; e Mariano Tommasi e Andrés Velasco, “Where Are We in Political Economy of Reform?”, Journal of Policy Reform, vol. 1 (1996).

${ }^{39}$ Lawrence Broz, "Political Institutions and the Transparency of Monetary Policy Commitmenrs", trabalho apresentado no encontro anual da American Political Science Association, Atlanta, Ga. 2-5 de setembro de 1999.
} 
soas podem facilmente discernir quando o compromisso é mantido ou quebrado. Por isso, taxas de câmbio fixadas permitem que os governos comprem ou emprestem credibilidade em momentos de dúvida. Quanto maior a não transparência das tomadas de decisão públicas, maior a necessidade de se vincular a uma taxa de câmbio fixa.

Esse argumento explica a decisão da Venezuela de aderir a uma taxa de câmbio semi-fixada em 1998. Num primeiro momento, o argumento não parece aplicar-se, visto que Broz explicitamente relaciona a timidez com altos níveis de comportamento não democrático, o que não se adapta à condição da Venezuela como regime democrático. Todavia, a não-transparência poderia estar relacionada com a condição de reformas defasadas. Os problemas econômicos e políticos que surgiram como resultado dos repetidos fracassos da Venezuela em fazer reformas esfumaçaram os contornos da política econômica, causando efeitos similares aos das instituições políticas não transparentes.

\section{Probabilidade de Fracasso e Resolução Acumulada}

Enfim, o fator mais decisivo para explicar a decisão do governo de evitar uma desvalorização foi sua própria avaliação das probabilidades de fracasso de cada opção político-econômica. O pior palco para ambas as opções políticas era o mesmo: inabilidade de conter as expectativas de desvalorização, provocando uma desvalorização maior do que a prevista, ou que "ultrapassasse" a taxa de câmbio, como ocorreu com o México em 1994. Os membros do governo calcularam que esse resultado tinha mais probabilidade de ocorrer se se tentasse um pacote de desvalorização somado a reformas, em vez de uma política de defesa da taxa de câmbio.

O governo percebeu que era politicamente inábil para implantar um pacote de reformas fiscais, com certeza não naquela altura da sua administração nem tão perto de uma eleição. Além disso, os policy makers estavam desconfiados da incompetência e fragilidade da maioria das outras agências estatais. $\mathrm{O}$ ministro do Planejamento (Cordiplan) poderia ter anunciado um programa de reformas estruturais, como sugerido pelo FMI, mas um programa desse tipo teria tido pouca credibilidade dada a desordem das finanças públicas, o ceticismo dos agentes econômicos e a influência repressora dos grupos de pressão e dos políticos populistas implicados na política fiscal ${ }^{40}$. Além do mais, a implementação seria adiada até que

\footnotetext{
${ }^{40}$ Em setembro de 1998, o Congresso aprovou uma "lei de poderes especiais" (ley habilitante) que autorizava o Executivo nacional a sancionar oito diferentes reformas por decreto, inclusive o tão necessário Fondo de Estabilización Macroeconómica. Todavia, esse comprometimento do Congresso em reformar era pequeno demais, tardio demais e efêmero demais. Era pequeno demais porque não resolveu completamente o déficit fiscal, que autorizava gastos com pessoal que de longe excediam os aumentos esperados das arrecadações de impostos. Era tardio demais porque ocorreu quando a crise estava chegando ao fim. E era efêmero demais porque antes que o ano acabasse, o mesmo Congresso aprovou sete novos créditos, o que fez com que o Orçamento final de 1998 produzisse o mesmo nível
} 
o novo governo assumisse. Portanto, uma desvalorização teria simplesmente exacerbado as razões pelas quais os agentes estavam em pânico, aumentando, assim, a chance de fracasso de uma política.

Supunha-se que a probabilidade de fracasso na defesa da moeda era menor. Em parte, a razão dessa avaliação tinha a ver com "fatores de recursos" como o alto nível de reservas bancárias e o quase-monopólio na oferta de câmbio. Todavia, no passado alguns recursos semelhantes haviam falhado na prevenção de que as crises monetárias se tornassem maxidesvalorizações. A causa era que altos níveis de reservas eram facilmente esgotáveis, como inúmeras crises monetárias nos anos 90 provaram. No México (1994), Tailândia (1997), Rússia (1998) e Brasil (1999), quanto mais se usavam as reservas para deter o ataque especulativo, menos munição sobrava, o que por conseguinte diminuía a capacidade de cada Estado de sinalizar para uma resistência. De fato, conforme as reservas iam declinando, os especuladores iam tendo todos mais razões para esperar por uma desvalorização próxima. É por isso que o uso das reservas para deter um ataque monetário facilmente exacerba, em vez de diminuir, as expectativas de desvalorização.

Os recursos, portanto, não são a razão que está por trás da maior confiança por parte do governo numa política de defesa da taxa de câmbio. Em vez do nível de reservas, o governo contou com suas "resoluções acumuladas". Com isso, quero dizer os fatores institucionais que permitiram ao Banco Central aderir a um caminho político escolhido. Esses fatores eram: (1) prioridade dada às reformas institucionais; (2) harmonização entre governo e Banco; e (3) histórico de consistência política.

Reformas Institucionais: Desenvolvimento da Independência Legal do Banco Central - O Banco Central da Venezuela era um exemplo de instituição assimétrica típica de Estados de reformas defasadas: era uma das poucas instituições públicas que haviam sido modernizadas de acordo com um processo de reformas, ainda que operasse em meio a instituições não reformadas. Em 1992, durante os últimos meses da administração Pérez, a nova "Lei do Banco Central" foi aprovada, estabelecendo a autonomia do Banco Central. Anteriormente, o Banco Central teve um corpo altamente politizado: o ministro das Finanças (entidade cuja tarefa principal era desembolsar os fundos públicos, sendo, assim, a mais suscetível às pressões lobbistas) tinha controle sobre as decisões dos diretores. Além disso, o quadro dos diretores do banco incluía representantes dos setores dos negócios, dos negócios bancários e trabalhistas. Tudo isso essencialmente garantiu a influência setorial e partidária sobre os policy makers do Banco Central.

A reforma de 1992 mudou isso. Os representantes setoriais foram tirados do quadro dos diretores e o ministro das Finanças perdeu o controle sobre as decisões dos diretores. O Banco Central foi encarregado da missão de "criar e manter con-

de gastos conforme projetado no começo do ano fiscal (ver Congreso de la República, Informe de coyntura). 
dições monetárias, de crédito e troca que incentivassem a estabilidade da moeda. ${ }^{41}$ Além disso, o Banco foi proibido de representar papéis de "desenvolvimento econômico", como fornecer subsídios quase-fiscais, oferecer diferentes serviços aos setores privado e público e assistência econômica de emergência a entidades insolventes. Em outras palavras, a lei de 1992 produziu o desenvolvimento da autonomia legal, que provou ser um trunfo durante a crise de 1998. A autonomia legal permitiu que o Banco evitasse os enormes clamores setoriais e partidários por uma desvalorização.

Harmonização entre Governo e Banco: O Desenvolvimento de uma Real Independência do Banco Central - A autonomia legal não é suficiente para garantir a independência do Banco Central. Os governos facilmente encontram mecanismos informais para violar a autonomia do Banco Central. Por isso, os especialistas fazem uma distinção entre a independência legal e a real do Banco Central. Muitos argumentam que esta última depende de outros fatores menos estruturados, tais como os acordos informais entre o Banco Central e outras partes do governo. ${ }^{42} \mathrm{Na}$ verdade, durante os primeiros dois anos da administração Caldera, o governo violou a independência real do Banco Central. Por exemplo, Caldera ignorou as recomendações do Banco Central sobre como lidar com a crise bancária de 1994, forçando o então presidente do Banco, Ruth de Krivoy, a renunciar em maio daquele mesmo ano. Caldera também estabeleceu controles nas taxas cambiais contra os desejos do Banco, que se recusou a endossar essa política, o que forçou o governo a entregar o gerenciamento dos mecanismos de controle ao PDVSA. Durante 1994-96, o governo e o Banco Central assumiram posições políticas separadas e antagônicas. Aquele estava buscando a expansão fiscal e políticas de economia fechada; este estava sendo excluído das decisões-chave da política econômica e forçado a dar "mais passos para prever algumas variáveis... para desviar do caminho estabelecido pela nova Lei do Banco Central” - a acumulação involuntária de passivos. ${ }^{43}$

A relação sem harmonia mudou em meados de 1996 com a Agenda Venezuela. O governo e o Banco começaram a trabalhar juntos no planejamento e defesa da nova currency band (banda monetária). Os objetivos de política continuaram a divergir - o governo continuou incapaz de conter o desperdício fiscal -, mas as interações entre o governo e o Banco haviam melhorado significativamente. Pela primeira vez, o Banco Central tinha permissão para perseguir suas próprias políticas como quisesse, com apoio total do Executivo nacional. Durante 1998, Teo-

\footnotetext{
41 The Law of The Central Bank of Venezuela”, OffIcial Gazette (Caracas ), 4 de dezembro de 1992, artigo 2 .

${ }^{42}$ Alex Cukierman, Steven B. Webb, $e$ Bilin Neyapti, "Measuring the independence of Central Banks and its Effects on Policy Outcomes", World Bank Economic Review, vol. 6 (setembro de 1992), pp. 393- 401; Alex Cukierman, Central Bank Strategy. Credibility, and Independence: Theory and Evidence (MIT Press, 1994).

${ }^{43}$ Banco Central de Venezuela, 1998 Year-End Address by the President of the Central Bank of Venezuela (Caracas, 18 de dezembro de 1998), p. 4.
} 
doro Petkoff, ministro do Cordiplan, defendeu repetidamente em público cada política levada a cabo pelo Banco Central e condenou seus críticos. Essa mudança nas relações entre o governo e o Banco Central de falta de harmonia para harmonia constituiu o desenvolvimento daquilo que Sylvia Maxfield identifica como as duas liberdades cruciais que o Banco Central requer: "independência de" e "liberdade para". ${ }^{44}$

Consistência Política - Uma vez estabelecida a real independência em 1996, o Banco Central se tornou capaz de defender a consistência política - isto é, seguir políticas consistentes com seus objetivos pretendidos. O objetivo estabelecido pelo Banco era estabilizar a moeda, absorver a liquidez excessiva e controlar a inflação. Para alcançar esses objetivos, os governos devem defender uma mescla de política consistente: boa vontade para restringir o fornecimento de crédito (elevando as taxas de juros). Combinada com a vontade de suprir a demanda por dólares, essa política é impopular e retarda o crescimento econômico. Em 1994, o México falhou em defender essa mescla política, o que explica suas complicações nas taxas cambiais no fim daquele ano. Embora comprometido com os mesmos objetivos, o governo mexicano seguiu apenas um componente desse pacote: atendeu à demanda de dólares, mas não à necessidade de restringir o crédito. Em seu esforço para evitar uma recessão, as autoridades mexicanas, na verdade, diminuíram as taxas de juros ao longo de 1994. Expandir o fornecimento de crédito num contexto de fugas de capitais e esgotamento de reservas era, do ponto de vista econômico, derrotar a si mesmo. Era também, do ponto de vista político, insensato, porque demonstrava falta de resolução política. Essa inconsistência política ajudou a causar a crise do peso. A Venezuela depois de 1996, em contrapartida, aderiu à mistura política correta. As taxas de juros foram aumentadas durante cada corrida monetária de 1998. Isso era politicamente oneroso porque exacerbava a recessão, mas era politicamente frutífero porque permitia que o Banco demonstrasse resolução.

Em suma, as doações institucionais - autonomia legal, melhoria na relação governo-banco e consistência política - deram ao Banco um alto grau de resolução acumulada. Foi isso que fez com que os governantes confiassem na capacidade do Banco Central de derrotar as expectativas de desvalorização em meio a choques exógenos. ${ }^{45} \mathrm{E}$ foi essa resolução, em vez das reservas, que permitiu ao Estado derrotar o ataque à moeda. Diferentemente das reservas, a resolução é um recurso cumulativo, não esgotável: quanto mais é usada, maior seu poder de persuasão.

\footnotetext{
${ }^{44}$ Sylvia Maxfield, “A Brief History of Central Bank Independence in Developing Countries”, in Andreas Schedler, Larry Diamond e Marc F. Plattner, orgs., The Self-Restraining State (Boulder: Lynne Rienner, 1999), p. 285.

${ }^{45}$ Para recentes pesquisa mostrando a correlação entre a independência do Banco Central e o desempenho econômico, ver A berro Alesina e Lawrence H. Summers, "Central Bank Independence and Macroeconomic Performance: Some Comparative Evidence”, Journal of Monet, Credit and Banking (maio de 1993), pp. 151-62; e Cukierman, Central Bank Strategy. Menos atenção foi dada à correlação entre a independência do Banco Central e a política de taxa cambial do que este capítulo sugere que pode existir.
} 


\section{O FIM DO SISTEMA PARTIDÁRIO DA VENEZUELA E O FUTURO DAS REFORMAS ECONÔMICAS}

Embora as autoridades venezuelanas se tenham sucedido na defesa do bolívar, elas falharam em seu objetivo político mais importante: impedir a vitória eleitoral do candidato à presidente mais hostil à reforma de mercado, Hugo Chávez Frías. Chávez venceu confortavelmente a eleição presidencial de dezembro de 1998 e esmagou a oposição na eleição para delegados de uma nova Assembleia Constitucional em julho de 1999. No processo, os "históricos partidos" venezuelanos, AD e COPEI, foram dizimados. Embora esses partidos tenham feito figura relativamente forte nas eleições congressuais e governamentais de novembro de 1998, seus candidatos atraíram poucos votos na corrida presidencial de dezembro de 1998 e nas eleições de julho de 1999 para a Assembleia Constitucional. A nova Constituição da Venezuela, aprovada no final de dezembro de 1999, estende o mandato presidencial para seis anos.

Várias questões agora vêm à mente. Será que Chávez causará danos econômicos posteriores seguindo políticas estatistas? Sucumbirá ao mesmo padrão de reformas corta-relaxa-quebra que perturbou os seus predecessores? Ou surpreenderá os seus detratores e obterá êxito na ruptura desse ciclo para sempre? Enfim, dada a sua expressiva afinidade com o presidente peruano Alberto Fujimori, de estilo autocrático e antipartidário, será que Cháves seguirá uma reforma de caráter autoritário semelhante?

Se Chávez converter-se à economia de mercado, exatamente como o fizeram a maior parte dos presidentes latino-americanos nos anos 90, ele gozará de algumas condições políticas favoráveis. Primeiro, são muitos e altamente mobilizados os que apoiam Chávez, e o seu apoio a ele parece ser mais por devoção do que por contrato, baseado mais em seu carisma pessoal do que na expectativa de resultados políticos favoráveis. Isso dá ao presidente um significativo grau de liberdade de política pública, inclusive a liberdade para quebrar suas promessas populistas. Segundo, com o virtual colapso dos tradicionais partidos de oposição, Chávez tem um espaço para agir sem precedentes. Enfim, Chávez desfruta de uma escora financeira invejável. ${ }^{46}$ Enquanto o presidente Pérez, em 1989, teve que lidar com os problemas econômicos com meros $\$ 3$ bilhões em reservas e o presidente Caldera enfrentou uma crise financeira com menos de $\$ 10$ bilhões em reservas em 1994, Chávez assumiu o poder com mais de $\$ 14$ bilhões em reservas. Além disso, o preço do petróleo subiu vertiginosamente para $\$ 30$ por barril em meados de 2000, um aumento triplo desde o fim de $1998 .{ }^{47}$

\footnotetext{
${ }^{46}$ McCoy, "Chávez”.

${ }^{47}$ A administração Chávez teve muita influência nessa reviravolta no preço do petróleo. Criticando a administração Chávez por sua política de "inundação do mercado", o ministro da Energia de Chávez, Alí Rodriguez, fez um lobby com membros da OPEP e outros para reduzir a produção. Esses esforços tiveram sucesso, mandando os preços do petróleo ao seus mais altos níveis desde a Guerra do Golfo.
} 
Seria possível pensar que esse é um contexto ideal para implementação de reformas. Poucos presidentes com mente reformista gozam dessa combinação incomum de altos níveis de apoio popular, partidos de oposição devastados, e uma escora financeira substancial. Qualquer economista voltado para o mercado seria tentado a assinar embaixo como um membro da equipe de Chávez. Porém, três tendências contrapostas complicam esse cenário cor-de-rosa.

Compromisso presidencial. Quão provável é que Chávez abandone o estatismo? Até agora, os sinais são confusos. Por um lado, Chávez ainda tem que reverter o processo de reforma econômica. Chegou até mesmo a defender a política do Banco Central. É de longe um desempenho melhor do que o de Caldera, que durante seus primeiros seis meses no poder implementou as mais antiliberais políticas econômicas da América Latina nos anos 90. Talvez o enfraquecimento da oposição organizada tenha suavizado as tendências autocráticas de Chávez, na medida em que não há uma dissidência maior a combater. Todavia, Chávez não renunciou inequivocamente às táticas autocráticas e estatistas. ${ }^{48}$ Ele apoiou a apertura petrolera, mas reimplantou as leis "compre venezuelano" no setor petroleiro, reminiscências do período áureo de industrialização de substituição de importações na América Latina. ${ }^{49}$ Sua nova Constituição dá ao Estado enormes prerrogativas nos negócios econômicos. Chávez fala sobre a economia em termos vagos: "Em vez do dogma de mercado, proponho o desenvolvimento das crianças e da educação". ${ }^{50}$ Ele minou a autonomia do PDVSA, colocando aliados políticos próximos, inclusive militares, no gerenciamento da companhia e forçando a resignação de diretores mais autônomos. E em política, tende a proferir ameaças valentonas contra os dissidentes. Porque falhou em fazer distinções entre "si mesmo", "sua administração" e "o povo", ele parece insinuar que as críticas aos dois primeiros são equivalentes aos ataques contra o último. Durante julho de 2000 seu slogan preferido na campanha presidencial era "Tremam, oligarcas". ${ }^{51}$

A fragilidade da coalizão dominante. Como a coalizão dominante sob Caldera, a coalizão dominante de Chávez, Polo Patriótico, é uma mistura ad hoc e de última hora de partidos pequenos e marginais da esquerda e de setores militares, com o apoio de facções desertoras de alguns partidos tradicionais. Por isso, é provável que essa coalizão se confronte com uma instabilidade estrutural similar, senão pior. Dois fatores põem em risco essa coalizão e, portanto, qualquer esforço de reforma futuro: (1) divisão entre civis e militares; e (2) uma divisão entre reformadores e não reformadores. A primeira já produziu o primeiro maior terremoto político: no começo de

Ver Larry Rohter, “Venezuelan Calls Tune in OPEC's Price Tactics”, New York Times, 7 de abril de 2000, p. A10.

${ }^{48}$ Ver Javier Corrales, " Hugo Chávez Plays 'Simon Says”, Hopscotch. vol. 2, n. 2 (2000).

${ }^{49}$ El Nacional, 14 de agosto de 1999.

${ }^{50}$ El universal, 10 de agosto de 1999.

51 The Economist, 22 e 28 de julho de 2000, pp. 35-6. 
2000, um membro da direção da ala "militar" do Polo Patriótico, Francisco Arias Cardenas, rompeu com o governo e largou sua candidatura à Presidência em protesto contra a lenta velocidade em direção à revolução prometida e contra a excessiva influência dos líderes civis. Em julho de 2000, dois oficiais das Forças Armadas pediram, abertamente, a renúncia de Chávez. O último fator ainda não produziu graves tremores, mas isso pode mudar uma vez que o governo anuncie um sério programa de reformas econômicas. Nenhum dos partidos do Polo Patriótico é forte, o que pode levar os líderes do Polo a preferir usar os recursos do Estado para construir máquinas políticas em vez de perseguir reformas. E esses partidos, como os deslocados partidos tradicionais, não têm participado do rodízio de liderança, por isso, não podemos ter certeza de que eles estejam a par do pensamento econômico corrente. Além do mais, o que promoveu a aliança foi o desejo comum de destruir a AD. Agora que isso foi feito, não fica claro o que mais os mantém juntos.

Descontando a oposição. O governo pode cometer o erro de exagerar o tamanho do enfraquecimento e da destruição da oposição. Embora os velhos partidos estejam mais fracos, Chávez não seduziu a nação toda. Obteve quase $95 \%$ dos assentos nas eleições para a Assembleia Constitucional, mas a contagem real dos votos foi menos esmagadora: os candidatos de Chávez obtiveram $63 \%$ dos votos em Caracas e $56 \%$ dos votos nas províncias. Além disso, o governo falhou em evitar uma espetacular taxa de abstenção de 54\%. Foi o sistema eleitoral e a fragmentação da oposição, ao invés de um presumido "apoio esmagador ao governo", que traduziram essa contagem dos votos para 95\% do controle da Assembleia Constitucional..$^{52}$ Vinte e nove por cento dos eleitores rejeitaram a nova Constituição. Nenhum membro da oposição a apoiou, um reflexo do alto grau de divisão entre governo e oposição na Venezuela.

Se Chávez continuar a não admitir essa separação, ele poderá muito bem pôr em risco suas chances de se tornar agora um reformador econômico bem-sucedido. As reformas econômicas são mais duradouras não quando são implementadas sem a concordância da oposição, mas quando os incumbentes tramam incentivos políticos que persuadam as forças da oposição a cooperar. ${ }^{53}$ Amedrontar a oposição não é maneira de conseguir fazer isso.

\footnotetext{
52 O sistema usado na eleição dos representantes para a Assembleia Constitucional (algumas vezes chamada de constituinte) foi "plurinominal". Não se pretendia agir como o primeiro pós-sistema do passado. Na prática, os candidatos com a maioria dos votos acabaram sendo eleitos em cada distrito. Além disso, nenhuma fórmula proporcional foi usada para garantir a representação de candidatos não majoritários. O governo distribuiu chuletas, gíria venezuelana para a "cola" usada pelos estudantes para trapacear nos exames. Essas chuletas listavam os candidatos preferidos do governo. Os eleitores prógoverno votaram de acordo com as chuletas. Os candidatos da oposição, relutando em se identificar com qualquer legenda partidária, não estavam interessados em tomar parte de nenhuma chuleta. Consequentemente, não houve sistema de coordenação dos votos da oposição, que ficaram dispersos. Ver Michael Penfold-Becerra, "Constituent Assembly in Venezuela, First Report”, mimeo., Carter Center, Emory University, Atlanta, 1999.

53 Jorge I. Domínguez, "Free Politics and Free Markets in Latin America “, Journal of Democracy, vol. 9 (outono de 1998 ), pp. 70-84.
} 
Em suma, muitas deficiências que impediram a consolidação das reformas no passado ainda persistem: oscilação do compromisso presidencial, uma fraca coalizão predominante, tendendo à fragmentação, partidos com lideranças imutáveis, e um desdém geral pelos partidos e críticos. O caminho para a consolidação da reforma permanece uma incógnita com obstáculos.

\section{CONCLUSÃO}

Este capítulo buscou ilustrar os perigos de ser um país com reformas defasadas. A Venezuela, em 1998, não era nem um caso de falta de implementação de reformas nem de se evitar reformas, mas, ao contrário, um caso de repetidos fracassos de reformas, estagnado, desde 1979, num padrão de reforma "corta-relaxa-quebra". Esse padrão de reformas, atribuível ao comportamento dos partidos políticos, teve consequências terríveis. Deixou a Venezuela com um conjunto de problemas econômicos não resolvidos, com uma coexistência ímpar de setores e instituições modernizadas e tradicionais, e uma aguda crise de credibilidade, levando ao cinismo em relação ao Estado e aos políticos. Isso explica por que os choques exógenos de 1997-98 tiveram um calamitoso efeito económico e político. A Venezuela pode não ter controlado a crise asiática, a queda dos preços do petróleo e a escolha do momento das eleições presidenciais de 1998, mas o seu padrão de reforma corta-relaxa-quebra a tornou particularmente suscetível a esses choques e mal preparada para reagir.

A teoria econômica-padrão ditou um pacote de desvalorização somado a um ajuste estrutural como reação adequada a esses choques. Mas a falta de credibilidade impossibilitou a implementação dessa opção. Os cidadãos não acreditariam nela. Os partidos não a permitiriam. Um ajuste baseado numa desvalorização estava, portanto, fadado a falhar.

Uma vantagem de ser um reformador com repetidos fracassos, em oposição àquele que evita urna reforma completa, foi o surgimento gradual de algumas instituições modernizadas - elas próprias legados de reformas precedentes - que o governo pôde capitalizar a seu favor. Uma instituição desse tipo foi um Banco Central mais autônomo. Este deu ao Estado seu mais importante trunfo: a capacidade de seguir uma política monetária restritiva e um regime cambial firme. Como resposta defensiva aos choques externos nos difíceis momentos econômicos, tais políticas eram menos do que favoráveis. Mas segui-las fez sentido, dado o contexto político particular. Desde 1996, o Banco Central tem demonstrado mais resolução do que qualquer outra entidade estatal. Foi, portanto, incompreensível que o governo lançasse mão de uma entidade estatal que havia mostrado semelhante competência.

No fim, a decisão de defender a moeda foi, essencialmente, uma decisão política para submeter a confecção de políticas econômicas ao Banco Central frente à incompetência governamental em outras áreas do gerenciamento econômico. As motivações para essa escolha foram similares àquelas que levaram a Argentina a 
estabelecer a Lei da Convertibilidade em 1991: a necessidade de recuperar a confiança dos agentes econômicos num contexto de alternativas limitadas e imensa falta de credibilidade. ${ }^{54}$ No entanto, a dinâmica era diferente. Na Argentina a Lei da Convertibilidade foi promulgada como um mecanismo para ganhar credibilidade atando as mãos dos artífices de políticas econômicas (a lei proíbe o Executivo de ajustar o regime de taxa cambial ou de usar as reservas para apoiá-lo), enquanto na Venezuela a lógica era ganhar credibilidade através de delegação institucional. Porque não podia administrar de maneira competente essa crise, o governo se rendeu à única autoridade que tinha chances de fazê-lo. Esse foi o motivo pelo qual o Banco Central, por meio da defesa da taxa cambial, emergiu como o principal protagonista dessa história.

A falta de credibilidade e a falta de transparência política ajudam a explicar a decisão da Venezuela de aferrar-se na defesa da moeda; mas não podem explicar seu sucesso em fazê-lo. A Argentina, até 1991, o México em 1994, a Venezuela em 1995- 96, a Colômbia e o Equador em 1997-98 e o Brasil em 1999 são exemplos notórios de esforços malogrados. O que explica o sucesso venezuelano em 1998 ? A resposta tem a ver com a natureza das relações entre o Banco Central e o governo, especificamente, com o surgimento da independência legal em 1992, a independência real em 1996, e a consistência política em 1998. Essas doações institucionais permitiram que o Banco Central mostrasse resoluções que, mais do que qualquer outra coisa, lhe permitiram derrotar as expectativas de desvalorização numa época em que todos os indicadores econômicos apontavam para a inevitabilidade de uma desvalorização.

Apesar do sucesso do Banco Central, a economia da Venezuela e o sistema político permaneceram frágeis, para dizer o mínimo. Não obstante a maior tranquilidade nos mercados financeiros internacionais, a recuperação dos preços do petróleo e o fim do período eleitoral, a recessão econômica na Venezuela, na verdade, se aprofundou em 1999. A incerteza quanto ao curso econômico da nova administração foi traduzida num real golpe nos investimentos. Segundo uma pesquisa industrial, $23 \%$ das firmas venezuelanas reduziram ou cancelaram seus planos de investimento em 1999. ${ }^{55}$ A tendência contínua de manter uma política monetária restritiva e um regime de taxa cambial firme junto com o desperdício e a incerteza macroeconômica é uma bomba prestes a explodir. Em outro lugar, essa combinação se mostrou insustentável a longo prazo: "Uma das partes terá que revisar sua estratégia (ceder)". ${ }^{56} \mathrm{Na}$ Venezuela, em 1998, nenhuma das partes cedeu.

\footnotetext{
${ }^{54}$ Javier Corrales, “ Why Argentines Followed Cavallo: A Technopol between Democracy and Economic Reform”, in Jorge I. Domínguez, org., Technopols: Freeing Politics and Markets in Latin America in the 1990s (Pennsylvania State University Press, 1997), pp. 49-93.

${ }^{55}$ El nacional, 3 de setembro de 1999.

${ }^{56}$ Patrícia Pollard, "Central Bank independence and Economic Performance”, Federal Reserve Rank of St. Louis (julho-agosto de 1993), pp. 21-36.
} 
Ao contrário, foram a economia real e o sistema político que cederam, a julgar pela profundidade da recessão, pela paralisia do setor privado, pela posterior queda do padrão de vida, e pela extinção do sistema partidário. A Venezuela foi capaz de atravessar a tormenta de 1998 e de defender o bolívar, mas não fica claro se está politicamente mais bem preparada para suportar futuros choques. 